\title{
Strategy of Czech Medium-Sized Royal Towns with Regard to Tourism Development
}

\section{Dana Fialová / Nikol Jiroutová}

e-mail: dana.fialova@natur.cuni.cz,ni.mail@seznam.cz

Department of Social Geography and Regional Development, Faculty of Science, Charles University, Prague, Czech Republic

Fialová, D., \& Jiroutová, N. (2017). Strategy of Czech Medium-Sized Royal Towns with Regard to Tourism Development. Czech Journal of Tourism, 6(2), 187-220. DOI: 10.1515/cjot-2017-0010.

\begin{abstract}
The medium-sized historical towns in Czechia have at their disposal a preserved cultural heritage which constitutes important potential for tourism. Apart from some exceptions, these towns are rarely a destination of tourists, but rather of the visitors who come to visit them in connection with a targeted stay destination. They also choose them as an alternative to optional excursions, just from the destination of their stay (also from the place of their permanent residence). Based on the intensification indicators calculated from publicly accessible data, this study answers the question of what the position of tourism in the selected towns (Czech royal towns with the population size between 10,000 and 30,000 inhabitants) is. Based on the strategic documents, it analyses what strategies were chosen by the selected royal towns for their development. It also analyses whether the topic of tourism that can undoubtedly without doubts rely on its historical potential, declared by legislative protection of cultural heritage, is represented and what its importance is.
\end{abstract}

\section{Keywords}

Bohemia, royal towns, strategic planning, urban tourism, heritage conservation

JEL classification: L83, L88, Q56 


\section{Introduction}

Cultural heritage, especially its intangible form, has major potential for tourism development in Czechia (Vystoupil et al., 2011). Prague is naturally the most important magnet for tourists and visitors. This is due not only to its position of the capital (Dumbrovská \& Fialová 2014, 2016), but, above all, to its historical wealth. It is followed by Český Krumlov or deserted places in the form of castles and chateaux. Other towns of various sizes, too, have something to offer to their visitors. As a rule, they look for a "warranted" quality, often declared as their "trademark" (Fialová \& Nekolný, 2015; Kašková \& Chromý, 2015; Matlovičová, 2015), such as UNESCO. However, there may be another "trademark" that can be associated with the presence of cultural heritage. The designation "royal city" could become such a trademark. This domain granted by the kings of Bohemia ceased to exist legally, but time has not changed anything in the fact that these towns are a living proof of rich Czech history (Bohemian Royal Towns, 2013). In all, 72 royal or dowry towns, from which the queens derived their incomes, were designated in the Kingdom of Bohemia. Some of them were declared repeatedly. Thanks to their rich history, the towns have a number of architectonic monuments and tourist destinations. However, they are often only known in their closest vicinity. Are the decision-makers aware of this advantage, certainly of a comparative nature, and are they able to make the most of it in marketing?

Since tourism is one of the biggest and fastest growing economic branches, it is becoming an increasingly important factor of regional development at all hierarchical levels. How have the selected towns (Czech royal towns with the population size ranging between 10,000 and 30,000 inhabitants) proceeded to exploit their development potential, especially in the sphere of tourism development? This question will be answered, based on the analysis of strategic documents. The documents are supposed to have been drawn up by the towns, among others as an indispensable precondition allowing to join the competitions for the granting of financial means from various subsidy titles. The heritage conservation and the chance to be granted the financial means from the subsidy titles of the Ministry of Culture of the Czech Republic is one of the ways which helps conserve and embellish historical urban cores not only for tourism. According to Tittelbachová (2008, p. 207), the subsidy programmes enhancing tourism "are often an important instrument of regional policy. This is why the topic of tourism is always a major part of the Regional Development Strategy, the National Development Plan, regional development strategies and regional development programmes as well as development strategies of towns and villages." The presumption is that this argument is also true of the analysed royal towns, while the heritage conservation will be one of the main factors of sustainable tourism. 


\section{Theoretical basis}

\section{Strategic planning of the municipality development}

Until the 1980s, strategic planning was hardly taken into account (Albrechts, Haley, \& Kunzmann, 2003). However, the main European metropolises later found out that the instruments of mainstream planning and the projects focused on territory were insufficient and did not correspond with the demands of urban transformation (Albrechts \& Balducci, 2013). As McCourt (2013) states in his study, in order to achieve a transition from the routine, bureaucratic forms of governance towards the conceptual strategic planning, it is at first necessary to reform the civil service. However, he also stressed that due to the differing character of problematic situations and the varying political environment of the countries under study, there was no universal approach that could be applied if necessary.

McCourt (2013) is of the view that a successful reform of the civil service must start with "the Weberian model" of public administration, which tries to answer the question of how to create a stable and efficient governance in the countries that just gained independence. The whole approach is based on the classical model of bureaucracy whose ancient origin lies in the sphere of both the public and private sector. The principles of functioning arise from the functional division of labour, a qualified manpower, the preference to the public wealth and, above all, from the separation between politics and the elected politicians, as well as between the civil service and the appointed officials. The administration was quite centralised, but it was the best solution for the countries in which the government for its own use prevailed over the wealth of society until then (Lindauer \& Nunberg, 1994; McCourt, 2013). The second model describes decentralisation which has been a global trend. The whole model is based on the principle of subsidiarity or the delegation of the decision-making process as closest as possible to the people (Reichard, 1997; Evans, 2003). The relationships between the centre and the hinterland are weakened and the autonomy of the public administration is shifted to a lower level.

A basic change and relinquishment of the regular and foreseeable public administration was only brought by the "New Public Management" model in the 1990s (McCourt, 2013). It abandons the observance of strict rules. Accountability was transferred to the private sector (privatisation). Its entities had to observe minimum standards of offered services, based on the principles of quality, norms, values, accountability and transparency (McCourt \& Minogue, 2001). This created competition which enhanced performance, drove the whole system. There was another model: the "bottom-up" approach. It criticised the previously prevailing belief that there is a need of giving the tasks from the centre or "from above". Unlike the models with a bureaucratic focus, the "bottom-up" approach consists in the idea that the civic society has to have a say in the decision-making process because the ensuing changes will affect it most (Hirschman, 1970; McCourt, 2013). This strengthened the poor entities that had not shown the slightest interest in any decision-making before. It turned out that the performance of the public sector had also increased thanks to the projects in the sphere of finances and tax management that 
fought against corruption. The context of complex situations has the dimensions of time and space. As a result, if a single problem is resolved, other problems will always logically arise (McCourt, 2013). It is a task of strategic planning to predict the changes to some extent and to resolve them in the right way.

At present, strategic planning is a strongly discussed topic globally. However, the notion itself has not yet been quite accurately interpreted. Its assessment across various fields is contradictory. For all the EU efforts to unify the planning documents of its member countries, there are quite apparent differences that reflect social and economic priorities, the administrative system, political arrangement, culture and traditions (Ježek, 2013). However, any changes bringing about the implementation of strategic planning can be described as positive. Thanks to this, the branch organisation of state administrations changes, while innovative techniques are integrated. The influence of national policy weakens, while the integration of economic, environmental, cultural and social policies grows in the examined area. Civil servants cooperate with actors on various positions of economic and civic society, defining along with them the priority objectives of space that are to ensure sustainable development (Albrechts, Haley, \& Kunzmann, 2003). This is understood as "such a development that preserves the chance to satisfy basic life needs to current and future generations, while it does not at the same time reduce natural diversity, retaining the natural functions of an ecosystem" (Pásková \& Zelenka, 2002, p. 302).

A number of European countries have decided to proceed to a transition from the regulatory policy to strategic planning. The main reason was the necessity to develop the instruments that would intervene more directly, more coherently and also more selectively in social reality and development (Albrechts \& Balducci, 2013). Although strategic planning has become a global trend, the above-mentioned authors see the main cause of this transition at a purely practical level. The first reason is the awareness that bureaucratic techniques are not suitable to deal with the problems and challenges faced by the towns. The demands for decentralisation and subsidiarity are growing and along with them, their relationships. New, specific problems of public administration are arising, focusing on environmental questions, the quality of life and social cohesion. A major role is also played by the need of growth on the part of the towns and regions on the global scale that later helps within a gradual reduction of central financing. The implementation of strategic planning causes a multiplication of the number of actors and a growing complexity of the approval process. In addition, everything is accompanied by the search for new models of territorial integrity and dissemination of new principles of planning and programming (Albrechts \& Balducci, 2013).

According to Albrechts, Haley, and Kunzmann (2003, p. 155), the main effort of the European towns to implement strategic planning has the following eight causes:

- competitiveness,

- changes in financing of self-rule bodies (reduction of budgets at both the national and local levels),

- socio-cultural movements and changes in lifestyle (focus on environmentally sustainable economy, quality of life and the environment), 
- insistence on regional or local identity (despite globalisation and European integration),

- decentralisation (creation of multilevel administration),

- search for new objectives of territorial policy (to replace/complement a sector organisation),

- reaction to regional problems,

- increasing role of planning policy principles in Europe (promotion of strategic planning by EU officials).

Strategic planning is understood as "a social process through which a range of people in diverse institutional relations and positions come together to design plan-making processes and develop contents and strategies for the management of spatial change" (Healey, 2000). The strategic plan should constitute the basic reference development axes of a municipality within a determined timetable and it should coordinate strategic activities. However, this should not be a mere technicality, but a living material whose updating reflects both internal and external conditions of the life of the whole municipality. It should contribute to the creation of enhanced competitiveness, a maximum use of the potential of the municipality and the acquisition of the biggest possible amount of financial means for the implemention of the determined objectives (̌̌ehoř, 2010). When it comes to the development documents that have no exactly fixed period of validity, there is a general rule that they should not be updated along with a change in the political representation. This should only happen if both external and internal factors are changed so much that the needs and priorities of the town should be reconsidered (Strategic Plan of the Town of Mělník, 2012).

Strategic planning in the public administration focuses on the comprehensive development of the examined area. It looks for the chances to prevent the impact of negative development on the one hand, and for the support for the development prerequisites on the other (Perlín, 2001). It cannot be understood as an individual concept or procedure, but rather as an instrument of development with two basic features. First, this is the complexity of a long-term vision that determines the most essential problems, challenges and assumptions of the whole strategy. Second, it is the substance of the plan as a project devoted to the implementation and listing of the activities that must be implicitly performed. For the sake of the verification of the plan plausibility, short-term objectives can be used. However, they should not be central (Albrechts \& Balducci, 2013).

Like abroad, in the environment of Czechia, too, the content of the strategic plan is not closely specified. As a result, there is still the only general rule: the necessity to correspond with the strategies of higher territorial units, such as the Development Programme of the Territorial Unit of the Region, the Regional Operational Programme NUTS II and, above all, the Sustainable Development Strategy of the Czech Republic (Řehoř, 2010). When this conceptual document is drafted, the role is also played by the attitude of the town, whether it really wants to achieve real planning of the development of the municipality itself, or whether it only wants to fulfil the conditions with which 
to acquire subsidy titles. As it is difficult to measure the successfulness of the strategic plan, the difference is often very difficult to be distinguished (Perlín, 2001). When the strategic document is drafted, it is important to know the previous development, the current state of affairs and the definition of the future, expected state. The ways in which the municipality can reach the designated objective have to be outlined in detail in individual steps (ibidem).

According to Perlín (2001), the strategic plan should fulfil 7 criteria: longevity, openness, interconnection, plausibility, selectivity, systematic character and symmetry. It would be naïve to believe that the strategy could include all the problematic phenomena of the observed town. On this account, one has to adopt a selective approach to the determination of the priority axes and apply certain generalisation. At the same time, the strategic plan should symmetrically track down all the substantial branches that might have an influence on the future development. One should also bear in mind the internal interconnectedness of individual development aspects. Four years should be the minimum period for the strategy. This is the duration of one election term. However, the planning is much more frequent in the span of five, six or ten years. The designated objectives of the strategic plan must be realistic and attainable both from the financial and social point of view. The general public should take part in the creation of the strategy and the responsible team should be open to innovative approaches. It should not be ignored that the strategic plan is a living document that should be subjected to permanent evaluation of previous results.

Since the form, extent and degree of detail of the strategic plan is not determined beforehand anywhere, it solely depends on its customer's good intent. As described by Perlín (2001), there are two working techniques that may differ, but in practice, they are mostly combined. First, it is the "expert" method. It is based on the drafting of the document by a group of hired experts (professionals) who often have no relationship with the area in question and are only acquainted with it in the course of the work. This is associated both with advantages in the form of a lack of biases and disadvantages in the sense of limited knowledge of the environment. The experts mostly use available statistical data and they describe the individual phenomena in great detail thanks to the quality methodology. Both the successfulness, but also the biggest drawback of the method lie in the communication between the provider and customer/client, which means the future user of the strategy. In this method of drafting, local experts' participation is all but impossible.

Second, the "community" method. In it, the whole strategy basically results from the discussion of local experts. At first, they try to identify the main problems of the region and subsequently focus on their solution. In many respects, the whole process is more understandable and interconnected. The biggest drawback is a certain superficial attitude of the expert team which may not take into account some less visible problems of the region. Due to this, the strategic plan then ignores them (Perlín, 2001). Depending on the chosen method, a distinction can be made not only in the working techniques, but also in the resulting structure of the strategic document. However, it is always possible to identify its three main parts-an analysis, synthesis and forecast. 
Along with an abundant wealth of cultural heritage, the assessed towns can also boast of a long and rich history. However, if they are to be able to follow up successfully the years of past fame, they have to have well-drafted conceptual development frameworks. One of the assumptions was the idea that each selected municipality already had a strategic plan and regularly updated it if there was a need. There was also the assumption that most strategies were drawn up by the community method. It is financially more accessible, but also much more efficient and even if there is no uniform, acknowledged model of processing, there will be no major differences in the internal structure of documents.

\section{Heritage conservation}

Industrialisation has been quite rightly associated with the previously unprecedented economic boom that entirely changed the functioning of the society of the day. However, with regard to the considerate treatment of cultural heritage, this development stage was rather a time of darkness. A number of heritage sites that would be of a sizable cultural value at present were considered barriers to development at the time of unregulated urban sprawl. As a result, their brutal destruction was a routine affair. This is exemplified by the contours of the original urban fortifications or rampart gates that can be only very rarely seen now. If a well-thought and efficient conservation had not started in time in the Czech Lands, many more heritage sites would have probably vanished.

The start of cultural heritage conservation in the area of present-day Czechia goes back to the $18^{\text {th }}$ century when the absolutist Age of Enlightenment set down its basic rules. At that time, the interest focused on religious artefacts, magnificent manors and precious jewels. A significant shift in the development of state cultural heritage conservation only occurred during the rule of Maria Theresa and her Theresian reforms. The Austro-Hungarian heritage institutions were among the most modern ones in Europe in their era. In 1850, The Central Commission for Maintenance and Preservation of Construction Heritage was created at the Ministry of Trade, Industry and Public Works. Nine years later, it was transferred under the aegis of the Ministry of Religion and Education where it was primarily managed by architects. After 1872, its reach also included tangible heritage and in 1911, the commission became a professional office. All the previous norms remained valid also after the establishment of independent Czechoslovakia. They were only complemented by further regulations with regard to the ban on export of works of art and historical heritage. After the end of World War Two, the Beneš Decrees became essential documents for heritage conservation. According to them, hundreds of castles and chateaux, historical sites in the towns and also in the borderland were handed over to the state ownership. The heritage administration was passed to the newly founded National Cultural Commission. It took up the categorisation of cultural furniture in the sites. The Ministry of Education, Sciences and Arts designated the first 30 historical town cores as urban heritage reserves, establishing cooperation with the Church and Religious Affairs Office (Heritage Conservation in the Czech Republic, online). 
The Cultural Heritage Act No. 22/1958 Coll. only became the first comprehensive document. It defined the duties arising from the maintenance of cultural heritage. It included the decrees on the registration of cultural heritage, national cultural properties, heritage reserves, heritage protection zones, or the activities of the state heritage conservation commissions. As society was developing, the legislation soon became insufficient. This is why the new State Heritage Conservation Act No. 20/1987 Coll. was passed. It came into effect as of January 1, 1988. It brought fundamental changes in the previous understanding of legal heritage protection. It was the Ministry of Culture that started designating individual properties as cultural heritage and it also enrolled them into the Central List of Cultural Monuments. Nowadays, it controls the Heritage Inspection, which supervises the observance of the law, and the National Heritage Institute. The latter institution administers hundreds of publicly accessible heritage properties and organises state heritage conservation in the Czech Republic. The law has been many times amended and it is complemented by the decrees of the Ministry of Culture No. 187/2007 Coll., and No. 420/2008 Coll. A new law will come into force at the beginning of 2018 (Heritage Conservation in the Czech Republic, online).

The cultural heritage is enrolled in the Central List of Cultural Monuments of the Czech Republic, administered by the National Heritage Institute (2016). Its web portal MonumNet contains a freely accessible heritage catalogue (World Heritage, national cultural property, protected areas). A comprehensive map of the national cultural properties can also be found in the Tourism Atlas of the Czech Republic (Vystoupil et al., 2006). In Czechia, cultural properties are divided according to the following three degrees. The presented numbers are valid for 2016:

- National cultural property (NCP) - 304 in Czechia;

- Cultural property (CP) - 40,390 in Czechia;

- Local importance property (LIP).

For the sample of heritage sites, the heritage reserves are used and they are divided into:

- Urban heritage reserves (UHR) - 40 in Czechia;

- Village heritage reserves (VHR) - 61 in Czechia;

- Archaeological heritage reserves (AHR) - 8 in Czechia;

- Other heritage reserves (OHR) - 2 in Czechia.

Another category is constituted by heritage zones:

- Urban heritage zones (UHZ) - 255 in Czechia;

- Village heritage zones (VHZ) - 212 in Czechia;

- Other heritage zones (OHZ) - 25 in Czechia (Heritage stock, online).

To conclude, one cannot but cite UNESCO heritage sites. Their inclusion into the UNESCO World Heritage List is ensured by The World Heritage Committee. It cooperates with consultancy organisations and its decisions are based on their positions. Howe- 
ver, before the selected heritage sites are UNESCO-listed, they undergo a process of information collection and a systematic monitoring (Machová, 2016). The Czech UNESCO Heritage is a voluntary association of towns and villages of the Czech Republic within which the heritage site inscribed in the UNESCO World Heritage List (Czech UNESCO Heritage, online) is located. The UNESCO heritage sites are divided according to their nature into two categories:

- UNESCO tangible heritage - 12 in Czechia;

- UNESCO intangible heritage - 5 in Czechia.

Under Section 16 (2) of the State Heritage Conservation Act No. 20/1987 Coll., the Czech Ministry of Culture can provide the means from the state budget for the renewal of cultural heritage (Subsidy Programmes of the Ministry of Culture and Their Evaluation, online). In all, the ministry has 9 programmes (subsidy titles). Thanks to them, it helps to preserve the most valuable heritage for which the towns are eligible provided they have a completed regeneration programme of the urban heritage reserves and urban heritage zones (UHR and UHZ Regeneration Programme). The regeneration is to rehabilitate cultural values, but also to create the development hubs of business activities and environmental protection. The municipalities acquire the regeneration programmes following their own decisions, when the initiative may be prompted by the town bodies, state heritage conservation, land-use planning and even community groups. They take a large part in the financing of repairs (measures of the Czech Ministry of Culture, ref 63.382/2012 Heritage Conservation, 2013).

\section{Methodology}

In all, this study examines 24 royal towns. Specifically, these are Beroun, Čáslav, Domažlice, Dvůr Králové nad Labem, Chrudim, Jaroměř, Kadaň, Klatovy, Kutná Hora, Litoměřice, Louny, Mělník, Nymburk, Ostrov, Pelhřimov, Písek, Prachatice, Rakovník, Rokycany, Slaný, Sušice, Tachov, Vysoké Mýto and Žatec. The choice out of the 72 royal towns situated in Czechia was made according to two criteria-their area and size. The analysis covered the towns located in the historical land of Bohemia with the current population size between 10,000 and 30,000 inhabitants.

The characteristic of the examined royal towns was carried out from the viewpoint of their population size (CZSO, 2016a) and area (CZSO, 2016b). In addition, there was an examination with regard to the number of tourists, capacity of group accommodation facilities (GAF) and the relative rate of importance of tourism in a given destination, similar to the description in an article on tourism in the selected Central European towns (Dumbrovská \& Fialová, 2014). The secondary data from the Czech Statistical Office (CZSO) as of 2015 (Legner, 2017) served as sources. Based on them, a characterisation was made of the intensity of tourism activity in a given destination by means of the Defert's tourist function index (DF), tourism intensity rate (TIR), tourism load (TL) and 
net bed capacity use (NBCU) (Pásková \& Zelenka, 2002). The selected towns were also described by means of the data on the existence and size of the protected conservation area and its type, including the number of cultural heritage sites. The data were obtained from the relevant decrees of the Culture Ministry (from 1961 to 1992) and from the online accessible list of the heritage reserves and zones.

A detailed analysis, targeted at the topic of tourism, was carried out for strategic documents that were publicly accessible in 19 cases and were sent by the relevant authorities upon request in two cases. Three towns (Čáslav, Louny, and Rokycany) did not have any finished strategic plan. The authors found out what method had been applied to carry out the strategies. They were compared with regard to their internal structure which is sometimes quite apparent from the content of the strategic plan. The main objective was to find not only similarities, but also differences that might determine the exclusive position of some towns from the examined sample.

All the available development visions of the observed towns were analysed. For the sake of their interpretation, the depiction in the form of a "word cloud" (www.wordcloud. com, online) was chosen. This is a visual representation of the most frequently used words in the text whose relative frequency is described by the font size. At first, redundant word classes with no explanatory value in the word cluster (pronouns, prepositions, conjunctions, numerals, particles and interjections) had to be deleted from the texts. All the nouns in the text were converted to the basic form of the word unit (nominative in the singular), just like adjectives (positive in the singular) and verbs (infinitive). Besides, the names of the examined towns were withdrawn from the text because in some visions, they are repeated in almost every sentence. The word "town" was repeated as many as 93 times in total, quite overshadowing the importance of other words in the ranking, due to which it was withdrawn, too. The scheme itself was produced online and out of the total number of 1,758 words that arose from all the 20 available visions, the final processing of the scheme was entered by 1,426 of them. After all, duplicated words were merged, the number of the words stopped at 665, while roughly one-half of them was only once used in the texts. Within the next step, the development axes that are considered the most important output of the analytical part of the strategic document were explored. Given the fact that at this stage of research, 21, often quite large texts were observed, a graphic depiction in the form of a table seemed to provide the best overview.

In order to evaluate the real interest of municipalities in tourism, the implementation parts of the strategic documents and the degree of their processing were used. Information on specific projects that were to help tourism development served as observed indicators in the research into the data. In addition, the project development was watched for its detail, the timetable, specification of actors, information on the chances of financing and their follow-up periods. The whole process was also to find out which towns already know what they exactly need and whether they know how to achieve the outlined objectives. In the remaining towns, which are still looking for answers to their questions, it was also taken into account whether they are simply unable to cope with the sphere of tourism or whether the general quality of strategic documents is lower than expected. In the final output, five categories were created: 
A) Towns whose implementation part of the strategic plan has the nature of action plans, have similar problems, project specifications, timetable of works and financial demands.

B) Towns whose implementation part includes a listing of all the necessary measures that are to bring about tourism development, but without answers to the questions "When?", "Who?" and "For how much?"

C) Towns whose implementation parts indicate the direction which they would like to proceed, but they have not yet set down any specific tasks.

D) Towns that do not consider the sphere of tourism problematic, due to which they have not finished any specific projects for their development.

E) Towns that have not yet finished any strategic plan, due to which one cannot reveal their real interest in tourism development.

The regeneration programme of the urban heritage reserves and zones was another assessed document. The programmes of 18 towns are at disposal in the electronic form. This means that they were completed. Ten of them are publicly accessible and eight were acquired after the communication with representatives of the relevant authorities. The town of Tachov did not have the relevant document finished and five towns only had it in a printed form. In some cases, their loaning was made dependent on a financial payment with the references to their authors, but they did not provide the programme. No document defines the regeneration programme. It solely depends on its drafters' consideration. However, after taking a look in some documents, 10 basic points were constructed. These are based on their frequency. They are as follows:

1) Characteristic of the town - Description of town,

2) Characteristic of the town - Description of UHR/Z,

3) Characteristic of the town - Cultural heritage list,

4) Previous planning period - Description of performed work,

5) Previous planning period - Financing of performed work,

6) Ongoing planning period - Programme objectives and priorities,

7) Ongoing planning period - Responsible working group,

8) Ongoing planning period - Project reserve,

9) Ongoing planning period - Financial demands of projects,

10) Ongoing planning period - Time demands of projects.

These characteristic signs cover both previous and ongoing planning periods as well as the description of the environment of the town and the protected conservation area. Although the project reserve is clearly the most important sign of the programme quality, each of the described signs was eventually evaluated by one point. 


\section{Results}

\section{Observed characteristics of the selected towns}

The selected royal towns were characterized on the basis of their size (population and area) and basic indicators from the sphere of tourism. These are, along with the annual volume of tourists, the total number of GAFs and beds, also the data on the average number of beds in an accommodation facility and the listing of the performance characteristics (see Table 1). It might be suitable to include also the data on the number of visitors in partial tourism attractions in the individual towns. However, the data are usually accessible with many difficulties and it was even worse to compare them (Fialová \& Nekolný, 2017).

The role of an objective indicator of the intensity of tourism is played by the value of the Defert's tourist function. It compares the numbers of the visiting and visited population. Out of the examined sample of the royal towns, the lowest tourist function appears in the town of Jaroměř (0.4). It only has three accommodation facilities with 56 beds in them. In addition, there are no accommodation facilities in the adjoining fortress town of Josefov either. Obviously, the town welcomes one-day visitors rather than tourists. Similar signs are found in the town of Rokycany (1.1), Tachov (1.2), Louny (1.2) or Chrudim (1.4). Taking into account their population size, they have fewer bed capacities than one might expect. The town of Pelhřimov is situated exactly at the level of the average (2.8), calculated from the whole sample of the towns. It is also located roughly in the middle of the size order. The value of the Defert's tourist function is not associated with the town size at all. This is why the main relationships should be looked for in the attractiveness of the heritage background, the multifunctional character of the facility and also in the position in the national transport network. This statement is also confirmed by the highest calculated value of the tourist function in Prachatice (6.2). It is, at the same time, one of the smallest examined towns (11,055 inhabitants). Compared with other towns, Prachatice does not excel with the area of its heritage reserve that only measures 12 hectares. However, it should be mentioned on the other hand that there is an unprecedented, large number of cultural properties (135) in such a small area. In this case, they are the main tourist attractions (Strategic Development Plan of the Town of Prachatice, 2016). However, even the number of cultural properties does not have any significant correlation with the value of the tourist function. This is proven by the case of the town of Žatec, which, with its 136 cultural properties (Šilhavá, 2016), only has a below-average value of the function (2.1). In Table 1, one can also find higher values in the town of Mělník (4.0) and Písek (5.1). Their number of cultural properties also does not provide them with any prominent places within the framework of the examined sample. A similar number of accommodation facilities as in Písek is in Kutná Hora (22), too. However, it only has a roughly one-half of the beds (784), due to which the tourist function is much smaller (3.9).

The tourism intensity rate, denoted by the abbreviation "TIR" (Pásková \& Zelenka, 2002, p. 80), expresses the annual number of tourists per 100 town residents. All the towns that receive over 20,000 tourists annually (Beroun, Dvưr Králové nad Labem, Kut- 
ná Hora, Mělník, Nymburk, Písek) have their TIR per 100 residents over 100 . The towns with 10,000-20,000 tourists (Klatovy, Litoměřice, Slaný, Žatec) have the value of TIR over 70, but it does not exceed 100 in any of them. However, there is one exception, in the case of the royal town Prachatice. Given its population size, the town is seen by more tourists than expected each year. By far the lowest number of tourists per 100 residents was calculated in Tachov (14) and also in Jaroměř (21) in 2015. Very few $(8,577)$ tourists also go to Chrudim, although with its accommodation capacities it is relatively well prepared for a tourist influx. However, there were no other anomalies in the examined towns and the results are hardly surprising.

"TL" or the tourism load index expresses the density of permanent beds in group accommodation facilities per one square kilometre. Here, the deviations from the capacity data are somewhat more visible since the differences in the area of the examined towns are quite apparent (see Table 1). Litoměřice has the biggest TL value with almost 49 beds $/ 1 \mathrm{~km}^{2}$. In this case, the data on the size of the town $\left(18 \mathrm{~km}^{2}\right)$ should not go unnoticed since it is surprisingly small. No wonder that in the town of Klatovy, whose area is almost four times higher, while its population size is similar, the TL only reaches 6.6. Out of the towns with over 20,000 residents, it is by far the lowest value. When it comes to the towns with a smaller population, approximately with less than 15,000 inhabitants, the highest concentration of beds is situated in the town of Nymburk (27.5). However, of a bigger interest is the value of TL (17.6) in Prachatice with its 11,000 inhabitants. With a relatively small population, it has quite a large area $\left(38.9 \mathrm{~km}^{2}\right)$. Apart from the abovementioned Litoměřice, over 20 beds per $1 \mathrm{~km}^{2}$ also occur in Beroun (23.5), Kutná Hora (23.7), Rakovník (23.9), Písek (23.9), Nymburk (27.5) and Mělník (31.1). By contrast, the smallest concentration of beds appears in the town of Jaroměr̆, similar to other performance characteristics. By far the best indicator for the presented study would emerge if the tourism load index were only analysed for the urban heritage reserves and zones. However, since suitable secondary data for this research are unavailable, this characteristic was at least presented as a whole for the entire urban district.

The value "NBCU" or net bed capacity use was included in the last column of Table 1. This indicator expresses the percentage proportion of really used beds in the royal towns in the course of the year, specifically in 2015. The average annual use of beds in Czechia amounts to $37.5 \%$ (The Number of Group Accommodation Facilities and Beds, online). However, out of the examined sample of royal towns, almost one quarter (Beroun, Dvůr Králové nad Labem, Jaroměř, Nymburk, Slaný) do not reach even this value. In Jaroměr̆, the NBCU of $46.7 \%$ is reached thanks to a very small number of accommodation capacities ( 3 GAFs, 56 beds), but in Beroun (46.3\%) it is due to a very high number of incoming tourists (TIR $=177)$. A surprisingly low proportion of NBCU appears in Prachatice (14.4), which otherwise showed quite high values in the previous indicators. A similar situation is in Tachov (11.4), Kadaň (13.6), Pelhřimov (14.0), Rakovník (14.8) and Sušice (14.9). The average value of NBCU in all the examined towns is $29 \%$, a much lower figure than the national average.

To provide a better picture of the potential of the observed royal towns, Table 2 presents the size of the heritage zones and the number of the cultural heritage sites. 


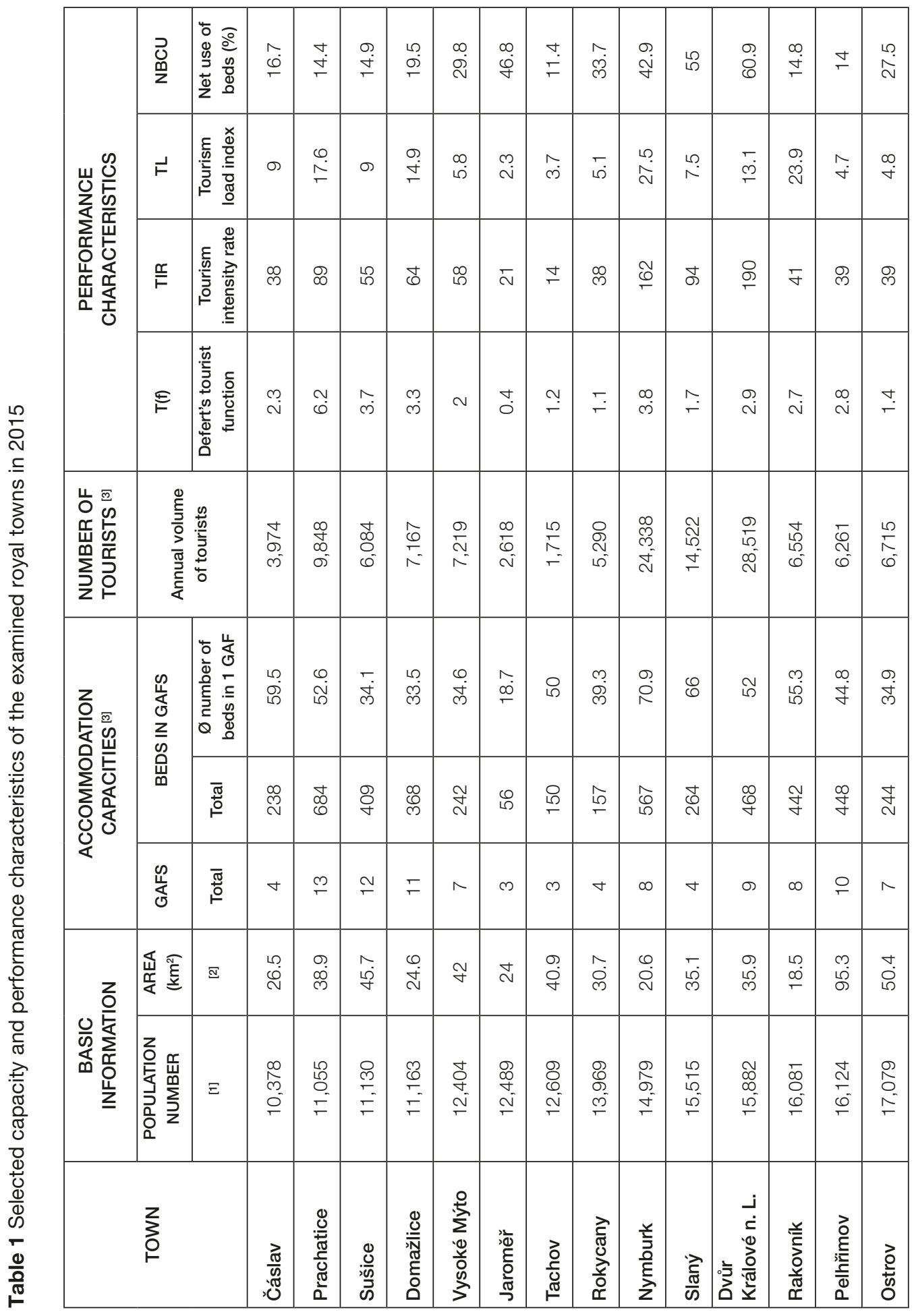




\begin{tabular}{|c|c|c|c|c|c|c|c|c|c|}
\hline $\begin{array}{l}\stackrel{0}{\dot{m}} \\
\stackrel{m}{\longrightarrow}\end{array}$ & Б্ & $\begin{array}{l}\text { ?ִ } \\
\stackrel{\theta}{9}\end{array}$ & 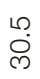 & חొ & $\begin{array}{l}0 \\
\text { } \\
\text { లె }\end{array}$ & 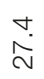 & 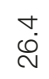 & $\stackrel{+}{\stackrel{\sim}{N}}$ & $\begin{array}{l}\stackrel{N}{N} \\
\text { }\end{array}$ \\
\hline$\hat{\sigma}$ & $\stackrel{m}{\sigma}$ & $\begin{array}{l}\stackrel{\llcorner}{\sim ్} \\
\text { Na }\end{array}$ & г. & $\stackrel{\leftrightarrow}{\circ}$ & $\hat{\infty}$ & $\stackrel{\varphi}{\dot{\theta}}$ & $\stackrel{\infty}{\infty}$ & $\begin{array}{l}0 \\
\infty \\
\infty \\
+\end{array}$ & $\begin{array}{l}\text { D্ } \\
\text { ' }\end{array}$ \\
\hline \& & $\stackrel{\infty}{\infty}$ & $\stackrel{\wedge}{\wedge}$ & $\stackrel{\mathbb{N}}{\sim}$ & 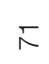 & $\stackrel{\stackrel{\sim}{\sim}}{\sim}$ & 8 & $\hat{\infty}$ & $\stackrel{\infty}{\sim}$ & $\stackrel{M}{\rightleftharpoons}$ \\
\hline$\stackrel{\mathscr{\omega}}{\ddot{\omega}}$ & $\stackrel{\sim}{\leftarrow}$ & $\begin{array}{l}\infty \\
\dot{\omega}\end{array}$ & $\nabla$ & $\bar{i}$ & $\begin{array}{l}\mathscr{\infty} \\
\ddot{\infty}\end{array}$ & $\stackrel{\stackrel{d}{\sim}}{ }$ & $\stackrel{\nabla}{\leftarrow}$ & $\stackrel{\bullet}{\dot{\rho}}$ & $\sigma_{0}$ \\
\hline $\begin{array}{l}\stackrel{0}{0} \\
\hat{6} \\
\infty 0^{-}\end{array}$ & $\begin{array}{l}\stackrel{+}{~} \\
\text { ঠ́ }\end{array}$ & $\begin{array}{l}\text { गे } \\
\text { O } \\
\text { ले }\end{array}$ & 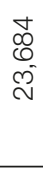 & 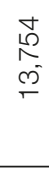 & $\begin{array}{l}\hat{\infty} \\
\infty \\
\omega \\
\sim \\
\sim\end{array}$ & 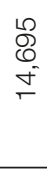 & $\begin{array}{l}\hat{N} \\
\hat{\infty} \\
\infty \\
\infty\end{array}$ & $\begin{array}{l}\bar{N} \\
\underset{\infty}{\infty} \\
\stackrel{0}{-}\end{array}$ & $\begin{array}{l}\Omega \\
\hat{L} \\
\mathbb{\rho}^{-}\end{array}$ \\
\hline 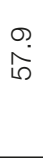 & $\stackrel{\llcorner}{\sim}$ & $\begin{array}{l}\text { D. } \\
\stackrel{0}{0}\end{array}$ & $\begin{array}{l}\infty \\
\dot{0}\end{array}$ & $\bar{\checkmark}$ & $\begin{array}{l}0 \\
\text { p. }\end{array}$ & $\underset{\infty}{\stackrel{\sim}{\infty}}$ & $\begin{array}{l}\stackrel{\infty}{\infty} \\
\stackrel{N}{N}\end{array}$ & $\begin{array}{l}0 \\
\dot{\sigma}\end{array}$ & $\stackrel{\hat{\rho}}{0}$ \\
\hline ్ֶలి & $\stackrel{\llcorner}{\underset{N}{N}}$ & 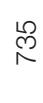 & $\stackrel{\wedge}{\wedge}$ & $\frac{}{\gamma}$ & \begin{tabular}{l}
\multirow{D}{\sim}{} \\
$\wedge$
\end{tabular} & 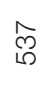 & 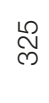 & $\underset{\infty}{\stackrel{N}{N}}$ & $\stackrel{N}{\frac{N}{5}}$ \\
\hline$\mp$ & $\sigma$ & $\stackrel{m}{\longrightarrow}$ & $\stackrel{\simeq}{\simeq}$ & 우 & $\approx$ & $\stackrel{\nabla}{\leftarrow}$ & $F$ & $\stackrel{\varphi}{\leftarrow}$ & $\stackrel{\sim}{N}$ \\
\hline $\begin{array}{l}0 \\
\dot{0} \\
0\end{array}$ & $\stackrel{\ulcorner}{\stackrel{\sim}{d}}$ & $\frac{m}{\text { m. }}$ & $\stackrel{\llcorner}{\sim}$ & 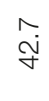 & ঙ্লি & $\begin{array}{l}\text { @) } \\
\dot{\infty}\end{array}$ & $\begin{array}{l}\stackrel{N}{\infty} \\
\text { ले }\end{array}$ & $\stackrel{\infty}{-}$ & $\begin{array}{l}\stackrel{N}{\tilde{ల}} \\
\tilde{C}\end{array}$ \\
\hline $\begin{array}{l}\text { న } \\
\infty \\
\infty \\
\end{array}$ & 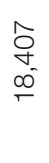 & 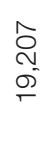 & 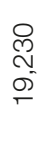 & $\begin{array}{l}\bar{N} \\
\stackrel{N}{\sigma} \\
\stackrel{\sigma}{+}\end{array}$ & $\begin{array}{l}\text { J } \\
\text { లે } \\
\stackrel{\text { }}{ }\end{array}$ & 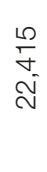 & $\begin{array}{l}\overline{\mathscr{Q}} \\
\mathcal{N}^{-}\end{array}$ & $\begin{array}{l}8 \\
\stackrel{0}{0} \\
\stackrel{-}{\sim}\end{array}$ & $\begin{array}{l}\infty \\
\infty \\
\infty \\
\stackrel{D}{N} \\
\stackrel{N}{\infty}\end{array}$ \\
\hline 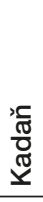 & $\begin{array}{l}\text { ઊે } \\
\text { ఏ઼ }\end{array}$ & 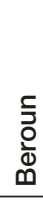 & 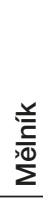 & $\begin{array}{l}\text { D } \\
\stackrel{\mathbb{N}}{\mathbb{N}} \\
\text {, }\end{array}$ & 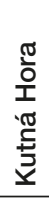 & 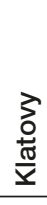 & $\begin{array}{l}\frac{\mathfrak{E}}{\overline{0}} \\
\frac{2}{\frac{2}{0}} \\
\end{array}$ & 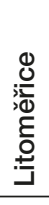 & 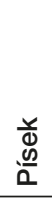 \\
\hline
\end{tabular}


Table 2 Urban heritage reserves and urban heritage zones in the examined royal towns

\begin{tabular}{|c|c|c|c|c|}
\hline TOWN & PROTECTION & $\begin{array}{c}\text { YEAR OF } \\
\text { DECLARATION }\end{array}$ & AREA (ha) & $\begin{array}{l}\text { NUMBER OF } \\
\text { CULTURAL } \\
\text { PROPERTIES }\end{array}$ \\
\hline Čáslav & $\mathrm{UHZ}{ }^{[1]}$ & $1992^{[3]}$ & $x$ & $63^{[29]}$ \\
\hline Prachatice & UHR [2] & $1981^{[5]}$ & $12^{[15]}$ & $135^{[15]}$ \\
\hline Sušice & $\mathrm{UHZ}{ }^{[1]}$ & $1992^{[3]}$ & $56^{[14]}$ & $60^{[14]}$ \\
\hline Domažlice & UHR ${ }^{[2]}$ & $1975^{[4]}$ & $17^{[13]}$ & $88^{[30]}$ \\
\hline Vysoké Mýto & $\mathrm{UHZ} \mathrm{Z}^{[1]}$ & $1990^{[6]}$ & $28^{[16]}$ & $41^{[31]}$ \\
\hline \multirow{2}{*}{ Jaroměř } & UHZ (Jaroměřr ${ }^{[1]}$ & $1990^{[6]}$ & $22^{[17]}$ & $82^{[17]}$ \\
\hline & UHR (Josefov) ${ }^{[2]}$ & $1971^{[7]}$ & $108^{[17]}$ & $116^{[17]}$ \\
\hline Tachov & $\mathrm{UHZ}{ }^{[1]}$ & $1992^{[3]}$ & $x$ & $29^{[32]}$ \\
\hline Rokycany & UHZ ${ }^{[1]}$ & $1992^{[3]}$ & $x$ & $40^{[33]}$ \\
\hline Nymburk & $\mathrm{UHZ}{ }^{[1]}$ & $1992^{[3]}$ & $20^{[18]}$ & $16^{[18]}$ \\
\hline Slaný & $\mathrm{UHZ}{ }^{[1]}$ & $1992^{[3]}$ & $41^{[19]}$ & $30[19]$ \\
\hline $\begin{array}{l}\text { Dvưr } \\
\text { Králové n. L. }\end{array}$ & $\mathrm{UHZ}{ }^{[1]}$ & $1990[6]$ & $x$ & $32^{[34]}$ \\
\hline Rakovník & $\mathrm{UHZ}{ }^{[1]}$ & $1992^{[3]}$ & $x$ & $23^{[35]}$ \\
\hline Pelhřimov & UHR ${ }^{[2]}$ & $1969^{[8]}$ & $6^{[20]}$ & $38^{[20]}$ \\
\hline Ostrov & $\mathrm{UHZ}{ }^{[1]}$ & $1992^{[3]}$ & $28^{[21]}$ & $39^{[21]}$ \\
\hline Kadaň & UHR ${ }^{[2]}$ & $1978^{[9]}$ & $33^{[22]}$ & $101^{[36]}$ \\
\hline Louny & $\mathrm{UHZ}{ }^{[1]}$ & $1992^{[3]}$ & $x$ & $49^{[37]}$ \\
\hline Beroun & $\mathrm{UHZ}{ }^{[1]}$ & $1992^{[3]}$ & $18^{[23]}$ & $15^{[23]}$ \\
\hline Mělník & $\mathrm{UHZ}{ }^{[1]}$ & $1992^{[3]}$ & $x$ & $51^{[38]}$ \\
\hline Žatec & UHR ${ }^{[2]}$ & $1961^{[10]}$ & $18^{[24]}$ & $136^{[24]}$ \\
\hline Kutná Hora & UHR [2] & $1961^{[10]}$ & $62^{[25]}$ & $319^{[25]}$ \\
\hline Klatovy & $\mathrm{UHZ}{ }^{[1]}$ & $1992^{[3]}$ & $34^{[26]}$ & $70^{[26]}$ \\
\hline Chrudim & $\mathrm{UHZ}{ }^{[1]}$ & $1990[6]$ & $52^{[27]}$ & $70^{[39]}$ \\
\hline Litoměřice & UHR ${ }^{[2]}$ & $1978[11]$ & $48[28]$ & $139^{[28]}$ \\
\hline Písek & $\mathrm{UHZ}{ }^{[1]}$ & $1990^{[12]}$ & $x$ & $46^{[40]}$ \\
\hline
\end{tabular}

Sources: [1-40] see in references 
Prachatice was the most often cited town, always in a positive sense. Despite its small population size on the one hand, and a large area on the other, it is able to attract a large number of tourists. It is thoroughly prepared for them. On the other hand, there is the town of Jaroměř whose capacities and numbers of tourists strongly lag behind. This finding is all the more bewildering that there is both a UHZ (Jaroměř) and a UHR (Josefov Fortress) within the bounds of the town.

\section{Strategic plans of selected towns}

The strategic documents analysed in this study are not comparable when it comes to their internal structure and, unfortunately, also the length and beginning of the planning period either. In some of the towns the length of the period is not firmly fixed. Only time will show the right moment for updating (Beroun, Kadaň, Mělník, Ostrov, Slaný). In other cases (Klatovy, Sušice), the validity of the document has already expired. Despite this, a new strategy has not been drafted. Three towns-Čáslav (Kožená, 2016, online communication, July 28, 2016), Louny (Krameriusová, 2016, online communication, September 14, 2016) and Rokycany (Hlad, 2016, telephone communication, November 7, 2016) - have not yet completed any strategy. However, the crushing majority of the considered documentation (Domažlice, Dvůr Králové nad Labem, Chrudim, Kutná Hora, Litoměřice, Nymburk, Pelhřimov, Písek, Prachatice, Rakovník, Tachov, Vysoké Mýto, Žatec) is still in force. Its validity will only expire during several years to come.

Although a uniform content of strategic documents has never been closely specified, a number of these plans are quite similar. In most cases, the strategies are carried out by regional development agencies and the companies that have no link to the town authorities. Professionally, this way of processing is called the expert method. Unlike the community method, it is initiated from above. The documents compiled in this way contain a very large analytical part, elaborated in the smallest detail, a detailed SWOT (strengths, weaknesses, opportunities and threats) analysis and a large number of objectives and measures. It cannot be said that such strategies are good for nothing. However, one has to realise that successful development of a community is mainly due to the implementation part drafted in a quality way and to the municipal authority that is able to implement the suggested proposals.

Surprisingly, one can only see in five cases that the town entrusted the creation of the strategic document to the staff of its own authority (Klatovy, Ostrov, Pelhřimov, Prachatice, Vysoké Mýto) uses the community method of drafting. In the remaining 16 cases, the work was performed by some agencies, companies or private architects who adopted an expert approach to the task.

Along with the objectives, the municipalities often set down development visions in the proposal part of the strategic document (̌̌ehoř, 2010). These are positive formulations of the desirable state of affairs the town wants to achieve by means of the strategic plan. If it is ignored that the municipalities in Čáslav, Louny and Rokycany do not yet have any development document, the town of Tachov is the only one not to have 
Figure 1 "Word cloud" of the most frequently used words in the development visions of the examined royal towns

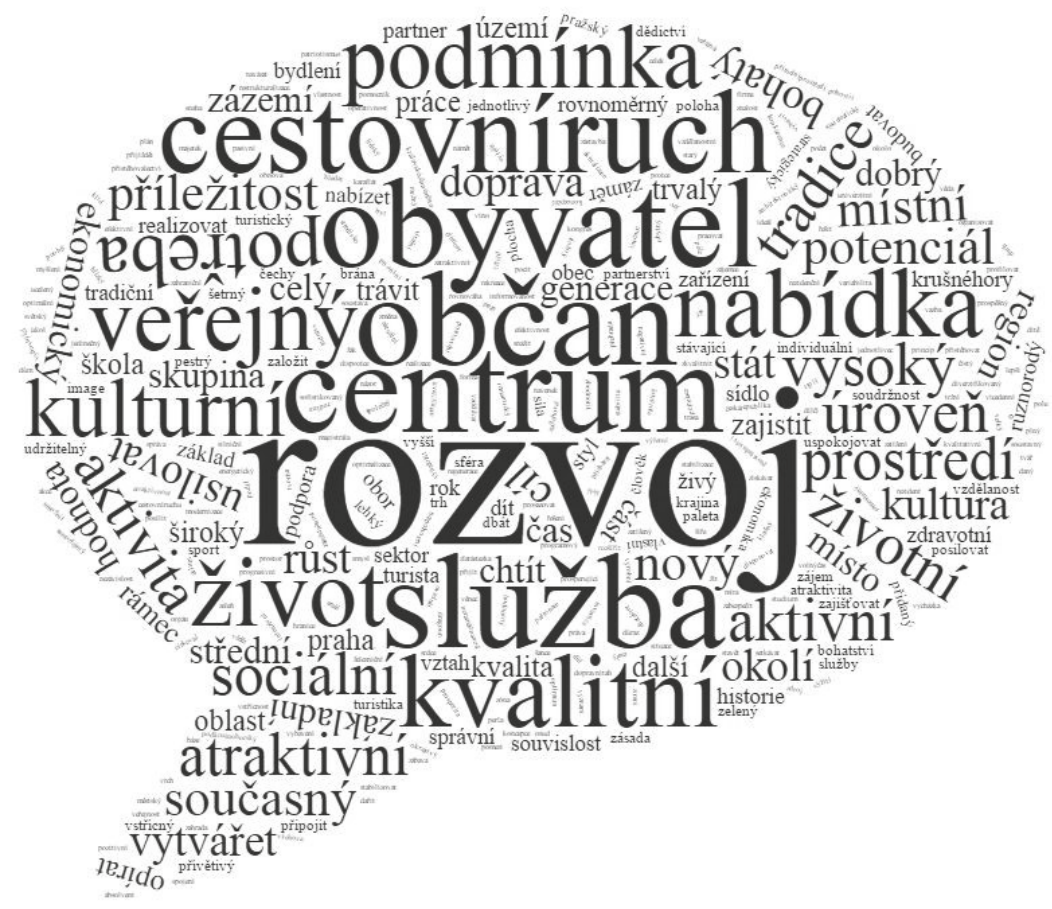

Note: The town of Čáslav, Louny and Rokycany do not yet have a completed strategic document

Source: Strategic Plans of the Selected Towns; Jiroutová (2017)

outlined its development vision. For the sake of an interpretation of the texts of visions from available strategies, a "word cloud" (Figure 1) was created. It is clear at first look what appeared most frequently in the visions of the selected towns. In addition, Table 3 depicts the 10 most used words along with the frequency of their occurrence in the development documents.

After the relevant refinement was made, it transpired that "development" is the second most used word, just after "town". It was repeatedly used by 8 towns, especially in connection with the infrastructure development, bilateral cooperation, external relations or the business environment. However, with regard to the association with tourism, which is the top priority for this study, the word "centre" is of much bigger importance. It was used 18 times. In all, it appeared in 11 texts, mostly in connection with tourism. The same frequency was revealed in the use of the words "citizen" and "service". The former is most often associated with satisfying the needs of citizens and civic society. The latter highlights the effort of the town to create an offer of quality services and to 
enhance their competitiveness on the labour market. The development of tourism-related services was recorded four times.

Table 3 Ten most frequently used words in the development visions of the examined royal towns

\begin{tabular}{|c|l|c|l|}
\hline & USED WORDS & FREQUENCY & USED IN DOCUMENTS OF TOWNS: \\
\hline $\mathbf{1}$ & TOWN & 93 times & Withdrawn from word cloud \\
\hline $\mathbf{2}$ & DEVELOPMENT & 30 times & $\begin{array}{l}\text { Beroun, Domažlice, Kadaň, Kutná Hora, Mělník, } \\
\text { Ostrov, Vysoké Mýto, Žatec }\end{array}$ \\
\hline $\mathbf{3}$ & CENTRE & 18 times & $\begin{array}{l}\text { Beroun, Dvưr Králové nad Labem, Jaroměř, Kadaň, } \\
\text { Kutná Hora, Mělník, Nymburk, Ostrov, Pelhřimov, } \\
\text { Rakovník Vysoké Mýto, Žatec }\end{array}$ \\
\hline $\mathbf{5}$ & SERVICE & 18 times & $\begin{array}{l}\text { Jaroměř, Kutná Hora, Mělník, Nymburk, Pelhřimov, } \\
\text { Prachatice, Vysoké Mýto, Žatec, }\end{array}$ \\
\hline $\mathbf{6}$ & RESIDENT & 17 times & $\begin{array}{l}\text { Beroun, Dvưr Králové nad Labem, Jaroměř, Kadaň, } \\
\text { Kutná Hora, Litoměřice, Mělník, Nymburk, Ostrov, } \\
\text { Pelhřimov, Prachatice, Rakovník, Vysoké Mýto }\end{array}$ \\
\hline $\mathbf{1 0}$ & LIFE & $\begin{array}{l}\text { Beroun, Domažlice, Dvưr Králové nad Labem, Jaroměř, } \\
\text { Kadaň, Kutná Hora, Nymburk, Ostrov, Pelhřimov, } \\
\text { Rakovník, Vysoké Mýto }\end{array}$ \\
\hline $\mathbf{8}$ & QUALITY & 16 times & $\begin{array}{l}\text { Beroun, Jaroměř, Kadaň, Klatovy, Kutná Hora, Mělník, } \\
\text { Nymburk, Ostrov, Rakovník, Slaný, Vysoké Mýto, Žatec }\end{array}$ \\
\hline & OFFER & 13 times & $\begin{array}{l}\text { Beroun, Dvưr Králové nad Labem, Chrudim, Jaroměř, } \\
\text { Kadaň, Kutná Hora, Litoměřice, Mělník, Ostrov, } \\
\text { Pelhřimov, Prachatice, Rakovník }\end{array}$ \\
\hline $\begin{array}{l}\text { Beroun, Domažlice, Dvůr Králové nad Labem, } \\
\text { Jaroměř, Kadaň, Kutná Hora, Nymburk, Pelhřimov }\end{array}$ \\
$\begin{array}{l}\text { Beroun, Dvưr Králové nad Labem, Chrudim, Kadaň, } \\
\text { Litoměřice Nymburk, Pelhřimov, Písek, Vysoké Mýto }\end{array}$ \\
\hline
\end{tabular}

Notes: The town of Čáslav, Louny and Rokycany do not yet have a completed strategic document; in the towns denoted in bold, the given expression reflects the topic of tourism

Source: Strategic Plans of the Selected Towns; Jiroutová (2017)

The word "resident" appears 17 times in the texts, but it does not reflect the observed topic at all. Quite on the contrary, there is the word "tourism", used by 12 towns in their development visions. Some of them want to continue with their support for tourism (Kutná Hora, Vysoké Mýto) and others consider themselves important destinations (Beroun, Jaroměř, Kadaň, Klatovy, Rakovník). The rest focus on the development of tourism-related services (Mělník, Nymburk, Ostrov, Slaný, Žatec). To draw up a universal 
vision that would include all the other words that were repeated in the presented visions at least ten times, they would describe the town as a place with high living standards and quality conditions for the development of private and public sectors. Thanks to the job offer, functioning public sector and a number of tourist attractions, they would be able to fully satisfy the needs of their population, business people and visitors. On top of that, there would be thorough environment conservation.

According to Kašková and Chromý (2015), "a good trademark" of tourist destinations is one of the basic attractions of a potential visitor. The study was based on the assumption that within the framework of Czechia, the domain of a "royal town" could also be the quality trademark. In fact, some of the examined towns are not royal towns. However, the analysis of the development visions of the strategic plans proved the opposite. It turned out that only the town of Litoměřice, Mělník, Nymburk, and Pelhřimov were really proud of this status.

Each development plan defines the objectives expressing what the community wants to achieve in the long run. The proposed development priorities, often also called development pillars or axes, are the most important output of the proposal part of the strategic document (̌̌ehoř, 2010). Table 4 depicts the most frequently used development axes in the strategic documents of the examined towns. In the rows, the objectives of the developments axes are depicted in descending order according to the frequency of use. In the columns, there are the names of the examined towns, lined up according to their size. In addition, the table includes the data on the total number of the development axes of the community because in some towns, the directions of development within the framework of a single axis focus on several spheres.

The results reveal that the economic growth, support for business and sufficient jobs are the most important axes. Economy is closely followed by the priority axes of tourism, heritage conservation and support for culture. According to the strategic plan of the town of Vysoké Mýto, the sphere focusing on the heritage conservation or tourism is not considered any priority because at present, it does not pose any major problems (Strategic Plan of Development of the Town of Vysoké Mýto-A Town of Comfort and Opportunities, 2014). This argument is confirmed by the vision of the town that only mentions tourism marginally. Písek is the second town that does not consider tourism development to be of vital importance. This does not mean that it ignores tourism development. It prefers as its priority the revitalisation of the selected attractive localities, a rehabilitation of its waterfront and a general embellishment of the town centre for its residents (Strategic Plan of the Development of the Town of Písek, 2015).

As stated by Řehoř (2010), the cultural heritage, tourism and the use of leisure time are among the priority spheres of strategic planning. The main objectives and measures with a priority focus on the sphere of tourism are described in detail in the strategies of 19 royal towns. However, one can find some differences in their quality and the detail of general elaboration. The role of the main factor, which classifies the described municipalities into various categories, was played by the development of the project reserve. It was followed by the solution to the problem of financing, the awareness of the entities in question, the estimates of the schedule of the works and the presumed impact of the 
changes. Just these factors helped to uncover which factors municipalities exactly know, what they need for the targeted tourism development and in which ways they plan to achieve them. They also help to single out those still groping their way when it comes to the solution to the question of sustainable development (see Table 5).

All the towns with elaborate, detailed specific activities and tasks within "the project reserve" fell within category A. Some projects were finished in full detail. It is quite obvious who is responsible for their execution, what financial means will be spent on them, when the projects will be finished and what their benefits to the town will be. The strategy of the town of Beroun also outlines in a well-arranged way in which stage of work each project is and whether the works continue according to the plan. In the strategies of the town of Rakovník and Slaný, specific tasks have the form of action plans that are updated in two-year intervals. One can presume that all 11 towns from category A will reach the desirable objectives because their strategies present a detailed instruction for the execution of the works.

However, the same cannot be said about the five towns classified within category B. Domažlice, Dvůr Králové nad Labem, Klatovy, Pelhřimov, and Prachatice have set down specific development activities. However, these strategies have the problem of not answering the basic questions (Perlín, 2001, p. 25) of "Who?" will be responsible for the projects, "When?" they will be implemented and not even "How much?" financial means will be spent on them. As a result, the objectives of the project part create the impression of empty words full of hopes, while there is no clear road leading to their fulfilment and there is no clear leader.

The third place is occupied by category C. It includes the towns which described the direction in which they would like to follow in smaller or greater detail, but they did not determine any specific tasks for this. This is why it is impossible to fully evaluate what their position on the given situation is or what steps the self-rule bodies of a town will have to take. Along with the town of Chrudim, Jaroměř, Litoměřice, Mělník and Sušice, this cluster includes a gem of Czech history, the town of Kutná Hora. It is comprehensible that due to its position as a UNESCO World Heritage-listed town, its priorities are clearly defined and processed (Kutná Hora - Management Plan, 2011). However, at this moment, there was an examination of the interest in tourism solely at the level of the strategic plan, in which the whole project is outlined quite briefly. In fact, the content of the strategy only describes the action plan and there is no connection to other documents or to the existing development programmes of the town.

The next sample, category $\mathrm{D}$, includes the towns which have a finished strategy, but they do not consider the sphere of tourism any priority. Due to this, a comparison with other towns is impossible (Písek, Vysoké Mýto). Category E is comprised of the towns without any drafted strategy: Čáslav, Louny, and Rokycany. 
Table 4 Most frequently used development axes in the development plans of the observed royal towns

\begin{tabular}{|c|c|c|c|c|c|c|c|c|c|c|c|c|c|c|c|c|c|c|c|c|c|c|c|c|c|}
\hline \multirow{3}{*}{ 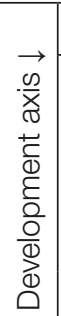 } & \multirow{3}{*}{ 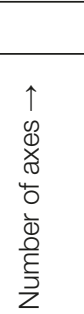 } & \multicolumn{22}{|c|}{ TOWN } & & \\
\hline & & 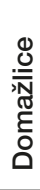 & 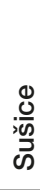 & 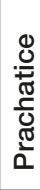 & 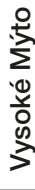 & 迹 & 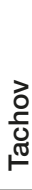 & है & $\frac{\text { त) }}{\text { क }}$ & 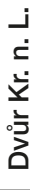 & 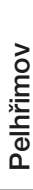 & 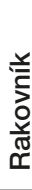 & $\frac{\partial}{0}$ & $\frac{1}{2}$ & d & אר & $\frac{5}{2}$ & 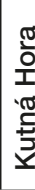 & $\frac{1}{5}$ & & & 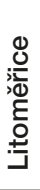 & $\begin{array}{l}\frac{y}{\Phi} \\
\stackrel{\mathscr{N}}{\alpha}\end{array}$ & & \\
\hline & & 6 & 5 & 8 & 6 & 9 & 5 & 3 & 3 & 7 & 5 & 3 & 4 & 6 & 2 & & 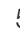 & 3 & 1 & & 4 & 5 & 3 & & \\
\hline \multicolumn{2}{|c|}{$\begin{array}{l}\text { Economy, } \\
\text { business, } \\
\text { employment }\end{array}$} & 0 & O & $\mathrm{O}$ & 0 & 0 & $\mathrm{O}$ & $\mathrm{O}$ & $\mathrm{O}$ & $\mathrm{O}$ & 0 & 0 & $\mathrm{O}$ & $c$ & & $c$ & $c$ & $\mathrm{O}$ & 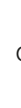 & & & $\mathrm{O}$ & $\mathrm{O}$ & \multirow{16}{*}{ 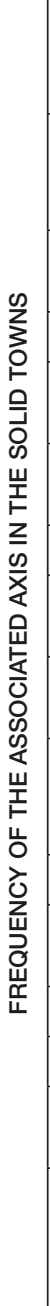 } & 20 \\
\hline \multicolumn{2}{|c|}{$\begin{array}{l}\text { Tourism, } \\
\text { culture, } \\
\text { heritage }\end{array}$} & 0 & $\mathrm{O}$ & 0 & & $\mathrm{O}$ & $\mathrm{O}$ & $\mathrm{O}$ & $\mathrm{O}$ & 0 & 0 & 0 & 0 & $c$ & $c$ & & $c$ & 0 & ( & & & $\mathrm{O}$ & & & 19 \\
\hline \multicolumn{2}{|c|}{$\begin{array}{l}\text { Transport } \\
\text { infrastructure }\end{array}$} & 0 & 0 & $\mathrm{O}$ & & 0 & $\mathrm{O}$ & $\mathrm{O}$ & $\mathrm{O}$ & $\mathrm{O}$ & $\mathrm{O}$ & $\mathrm{O}$ & & c & c & $c$ & ( & $\mathrm{O}$ & & & b & & $\mathrm{O}$ & & 17 \\
\hline \multicolumn{2}{|c|}{ Environment } & 0 & O & 0 & 0 & & $\mathrm{O}$ & 0 & & $\mathrm{O}$ & & $\mathrm{O}$ & & & & $c$ & 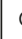 & & C & & b & 0 & & & 13 \\
\hline \multicolumn{2}{|c|}{$\begin{array}{l}\text { Technological } \\
\text { infrastructure }\end{array}$} & & O & $\mathrm{O}$ & & & & $\mathrm{O}$ & $\mathrm{O}$ & $\mathrm{O}$ & $\mathrm{O}$ & $\mathrm{O}$ & & $c$ & & $c$ & & $\mathrm{O}$ & 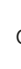 & & & & & & 11 \\
\hline \multicolumn{2}{|c|}{$\begin{array}{l}\text { Social care, } \\
\text { health care }\end{array}$} & & & $\mathrm{O}$ & 0 & & $\mathrm{O}$ & $\mathrm{O}$ & & $\mathrm{O}$ & & & & $c$ & $c$ & & & & 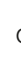 & & & $\mathrm{O}$ & & & 9 \\
\hline \multicolumn{2}{|c|}{ Housing } & 0 & & $\mathrm{O}$ & & 0 & & 0 & & & $\mathrm{O}$ & & & & & & & 0 & 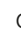 & & 0 & & & & 8 \\
\hline \multicolumn{2}{|c|}{$\begin{array}{l}\text { Public utilities, } \\
\text { public services }\end{array}$} & & $\mathrm{O}$ & & 0 & & O & & & & $\mathrm{O}$ & $\mathrm{O}$ & $\mathrm{O}$ & & & & 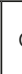 & & & & & & & & 7 \\
\hline \multicolumn{2}{|c|}{$\begin{array}{l}\text { Town } \\
\text { environment }\end{array}$} & & & & 0 & & & & & & & & 0 & $c$ & $c$ & & & & & & & $\mathrm{O}$ & $\mathrm{O}$ & & 6 \\
\hline \multicolumn{2}{|c|}{$\begin{array}{l}\text { Education, } \\
\text { science, } \\
\text { research, sport }\end{array}$} & & & $\mathrm{O}$ & 0 & & & & & $\mathrm{O}$ & & & & & & & & & $c$ & & & O & & & 6 \\
\hline \multicolumn{2}{|c|}{ Leisure time } & 0 & & 0 & 0 & 0 & & & & $\mathrm{O}$ & & & & & & & & & & & & & & & 6 \\
\hline \multicolumn{2}{|c|}{$\begin{array}{l}\text { Public } \\
\text { administration }\end{array}$} & & & $\mathrm{O}$ & & & & O & & & & & $\mathrm{O}$ & & & & & & & & & O & & & 5 \\
\hline \multicolumn{2}{|c|}{ Quality of life } & & & $\mathrm{O}$ & & & & & $\mathrm{O}$ & & $\mathrm{O}$ & & & & & $c$ & & & & & & & & & 4 \\
\hline \multicolumn{2}{|c|}{ Security } & & & & & & & & & & $\mathrm{O}$ & & & & & & & & c & & & & & & 2 \\
\hline \multicolumn{2}{|c|}{$\begin{array}{l}\text { Land-use } \\
\text { development }\end{array}$} & & & $\mathrm{O}$ & & & & & & & & & & & & & & & & & 0 & & & & 2 \\
\hline \multicolumn{2}{|c|}{$\begin{array}{l}\text { External } \\
\text { relations } \\
\text { of town, } \\
\text { cooperation }\end{array}$} & & & & & & & & & & & & & & & & & & 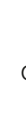 & & & & & & 1 \\
\hline
\end{tabular}

Notes: The town of Čáslav, Louny and Rokycany do not yet have a completed strategic document; occurrence "o"

Source: Strategic Plans of Selected Towns; Jiroutová (2017) 
Table 5 Category of interest in tourism with regard to strategic planning in the observed royal towns

\begin{tabular}{|c|c|c|c|c|c|c|c|c|c|}
\hline TOWN & 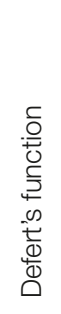 & 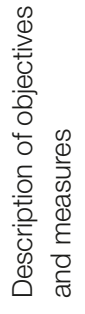 & 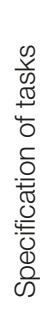 & 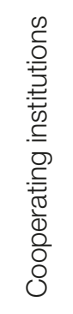 & 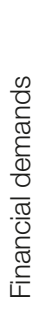 & 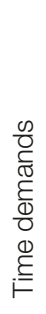 & 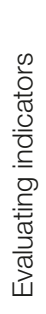 & 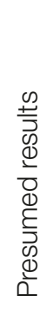 & 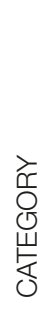 \\
\hline Beroun & 3,8 & 0 & 0 & $0 /-$ & 0 & 0 & o & o & \multirow{8}{*}{ A } \\
\hline Kadaň & 3,6 & 0 & 0 & $0 / 0$ & 0 & 0 & & & \\
\hline Nymburk & 3,8 & 0 & 0 & $0 / 0$ & 0 & 0 & & & \\
\hline Ostrov & 1,4 & o & 0 & $\mathrm{O} / \mathrm{O}$ & O & O & O & & \\
\hline Rakovník & 2,7 & 0 & 0 & & & & 0 & & \\
\hline Slaný & 1,7 & 0 & 0 & -10 & O & & 0 & & \\
\hline Tachov & 1,2 & 0 & 0 & & & 0 & 0 & 0 & \\
\hline Žatec & 2,1 & 0 & 0 & & & & & 0 & \\
\hline Domažlice & 3,3 & 0 & o & & & & & & \multirow{5}{*}{ B } \\
\hline Dvưr Králové n. L. & 2,9 & 0 & 0 & & o & & o & & \\
\hline Klatovy & 2,4 & 0 & 0 & & & & & & \\
\hline Pelhřimov & 2,8 & 0 & o & & & & & & \\
\hline Prachatice & 6,2 & 0 & 0 & & & & & & \\
\hline Jaroměř & 0,4 & 0 & & & & & & & \multirow{6}{*}{ C } \\
\hline Mělník & 4 & 0 & & & & & & & \\
\hline Kutná Hora & 3,9 & 0 & & & & & & & \\
\hline Chrudim & 1,4 & 0 & & & & & & & \\
\hline Litoměřice & 3,6 & 0 & & & & & & & \\
\hline Sušice & 3,7 & 0 & & & & & & & \\
\hline Vysoké Mýto & 2 & - & - & - & - & - & - & - & \multirow{2}{*}{$\mathrm{D}$} \\
\hline Písek & 5,1 & - & - & - & - & - & - & - & \\
\hline Čáslav & 2,3 & & & & & & & & \multirow{3}{*}{$E$} \\
\hline Louny & 1,2 & & & & & & & & \\
\hline Rokycany & 1,1 & - & - & - & - & - & - & - & \\
\hline
\end{tabular}

Note: "o" = occurrence

Source: Strategic Plans of the Selected Towns; Jiroutová (2017) 


\section{Regeneration plans of the heritage reserves and zones}

The regeneration programmes of UHRs and UHZs were developed in order to assist a comprehensive regeneration of the most valuable heritage sites of historical towns (Czech Government Resolution No. 209 from 1992, online). Unlike the strategic document, their drafting is strongly controlled and the law precisely stipulates which bodies should take part in their preparation. The results of the comparison of all 18 available documents from the ranks of the examined royal towns are outlined in Table 6.

In order to evaluate the internal structure and degree of the development of regeneration programmes, a choice was made of a point system for the most important characteristic features. The system was described in the methodological part. Although none of the communities have a perfectly drafted document in accordance with the chosen criteria, three of them (Slaný, Sušice, Vysoké Mýto) are very close to the goal. In all three towns, there is a vivid description of the town development, a characteristic of the heritage area and a list of cultural properties. In the summary of the previous planning period, only the town of Vysoké Mýto lacks a detailed description of the performed works. However, all of them have published their financial histories. In the ongoing plans, all towns have released the sufficient information on the project reserve, which is also complemented by a timetable.

The working group that is responsible for all the works has not yet been listed in the regeneration document of the town of Sušice. On the other hand, the town of Slaný does not share the presumed financial demands of the prepared works. The mentioned towns are followed by another three with the total of 7 points, whose regeneration programmes are also of very good quality. In its document, the town of Chrudim also refers to the strategic plan of the town and the tourism action plan. In the evaluation of the previous period, it only deals with the spent financial means, not with a detailed description of repairs. The project reserve for the years to come is also very abundant. However, if it is to be called perfect, it should not lack the budget description and the appointment of the working group. Litoměřice is another town with the gain of 7 points. It deals with the financial issue neither in the previous nor in the present planning periods. Unfortunately, it is unclear who is responsible for a smooth implementation of the programme in this case. From the small group, Prachatice is the last town. Its project reserve is quite large. Instead of the timetable, the individual projects have a scale of importance. However, the text lacks a description of the town, a comprehensive list of cultural properties or a responsible working group.

The final 6 points were gained by the town of Kadaň. It does not deal at all with the previous planning period and it has no list of cultural properties or an appointed working group. There is also the town of Louny which, along with the description of the town, also lacks a specification of the priorities of the ongoing period, a working group and a financial budget. The document which received 5 points, specifically the Regeneration Programme of the Town of Beroun, is also interesting. Although the strategic plan of this town does not identify tourism as its priority, its regeneration programme deals with some aspects of tourism in great detail (such as the regulation of front yards, 
Table 6 Qualitative processing of regeneration programmes in the examined royal towns

\begin{tabular}{|c|c|c|c|c|c|c|c|c|c|c|c|c|c|c|}
\hline \multirow[b]{3}{*}{$\sum_{1}^{3}$} & \multirow[b]{3}{*}{$\stackrel{u}{\gtrless}$} & \multirow[b]{3}{*}{ 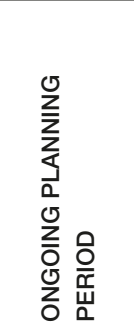 } & \multirow{2}{*}{\multicolumn{3}{|c|}{$\begin{array}{c}\text { CHARACTERISTIC } \\
\text { OF TOWN }\end{array}$}} & \multicolumn{7}{|c|}{ PLANNING PERIOD } & & \\
\hline & & & & & & \multicolumn{2}{|c|}{ PREVIOUS } & \multicolumn{5}{|c|}{ ONGOING } & & \\
\hline & & & 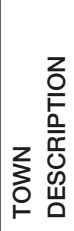 & 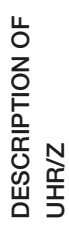 & $\begin{array}{l}\infty \\
0 \\
0 \\
0 \\
5 \\
\frac{5}{7}\end{array}$ & 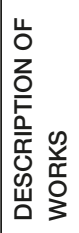 & 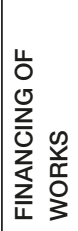 & 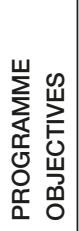 & $\begin{array}{l}0 \\
\frac{9}{2} \\
0 \\
\frac{0}{0} \\
0 \\
0 \\
\frac{1}{2} \\
\frac{1}{0} \\
0 \\
3\end{array}$ & 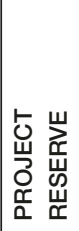 & 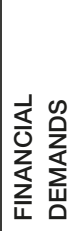 & 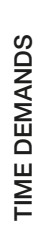 & & \\
\hline Slaný & $\mathrm{UHZ}$ & $2014-2018$ & $\mathrm{o}$ & o & $\mathrm{o}$ & o & 0 & o & o & o & $x$ & 0 & \multirow{18}{*}{ 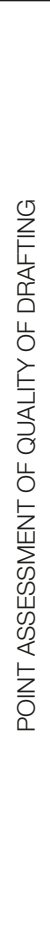 } & 9 \\
\hline Sušice & $\mathrm{UHZ}$ & 2016-2026 & $\mathrm{o}$ & o & o & 0 & 0 & o & $x$ & 0 & o & 0 & & 9 \\
\hline Vysoké Mýto & $\mathrm{UHZ}$ & 2014-2023 & $\mathrm{o}$ & 0 & 0 & $x$ & o & 0 & 0 & 0 & o & 0 & & 9 \\
\hline Chrudim & $\mathrm{UHZ}$ & $2013-2023$ & 0 & 0 & o & $x$ & 0 & o & $x$ & 0 & $x$ & 0 & & 7 \\
\hline Litoměřice & UHR & 2015-2020 & o & o & o & 0 & $x$ & o & $x$ & $\mathrm{O}$ & $x$ & 0 & & 7 \\
\hline Prachatice & UHR & 2016-2018 & $x$ & o & $x$ & 0 & o & o & $x$ & o & o & 0 & & 7 \\
\hline Kadaň & UHR & 2014-2018 & o & o & $x$ & $x$ & $x$ & o & $x$ & 0 & o & 0 & & 6 \\
\hline Louny & $\mathrm{UHZ}$ & 2011-2025 & $x$ & 0 & o & 0 & 0 & $x$ & $x$ & 0 & $x$ & 0 & & 6 \\
\hline Beroun & $\mathrm{UHZ}$ & 2016-2019 & $x$ & $x$ & $x$ & $x$ & $x$ & o & o & o & o & 0 & & 5 \\
\hline Rokycany & $\mathrm{UHZ}$ & 2016-2020 & $x$ & $x$ & o & 0 & o & $x$ & $x$ & 0 & $x$ & 0 & & 5 \\
\hline Kutná Hora & UHR & 2011-2016 & o & 0 & $x$ & 0 & 0 & $x$ & $x$ & $x$ & $x$ & $x$ & & 4 \\
\hline Klatovy & $\mathrm{UHZ}$ & 2011-2016 & $x$ & $x$ & $x$ & 0 & $x$ & $x$ & $x$ & 0 & $x$ & 0 & & 3 \\
\hline Ostrov & $\mathrm{UHZ}$ & 2010-2020 & $x$ & $x$ & $x$ & 0 & o & 0 & $x$ & $x$ & $x$ & $x$ & & 3 \\
\hline Písek & $\mathrm{UHZ}$ & 2015-2019 & $x$ & $x$ & $x$ & $x$ & $x$ & $x$ & $x$ & o & o & 0 & & 3 \\
\hline Čáslav & $\mathrm{UHZ}$ & each year & $x$ & $x$ & $x$ & o & o & $x$ & $x$ & $x$ & $x$ & $x$ & & 2 \\
\hline Pelhřimov & UHR & 2016-2020 & $x$ & o & o & $x$ & 0 & 0 & $x$ & $x$ & $x$ & $x$ & & 2 \\
\hline $\begin{array}{l}\text { Jaroměř (+ } \\
\text { Josefov) }\end{array}$ & $\begin{array}{l}\text { UHZ/ } \\
\text { UHR }\end{array}$ & each year & $x$ & $x$ & $x$ & $x$ & $x$ & $x$ & $x$ & $x$ & $x$ & $x$ & & 0 \\
\hline Žatec & UHR & each year & $x$ & $x$ & $x$ & $x$ & $x$ & $x$ & $x$ & $x$ & $x$ & $x$ & & 0 \\
\hline
\end{tabular}

Note: "o" = occurrence

Source: Regeneration Programmes of the Selected Towns, Jiroutová (2017) 
the elimination of advertising billboards, or making the town core attractive with Christmas decoration). However, the document absolutely lacks any description of the town, the heritage zone or its heritage sites, as well as the description of the previous planning period. The same number of points was scored by Rokycany, which has similar weaknesses as Beroun.

Only 4 points were gained by Kutná Hora. However, its heritage development is guided by a number of other documents. On the other hand, its regeneration programme itself is quite brief and does not even contain any project reserve. The same is true of the regeneration of the town of Ostrov, which only gained 3 points. It basically only looks like a single, long list of the problems, with no closer specification or timetable. The regeneration programme of Klatovy was written in a similar fashion. Unlike the previous document, its design is at least much better arranged. Three points were also given to the town of Písek. Its programme has a few pages that only contain the project reserve, its timetable and financial demands.

At the very bottom of Table 6, there are four towns whose documents are at a qualitatively lower level than those mentioned before (Čáslav, Jaroměř, Pelhřimov, Žatec). One cannot find a project reserve in any of the documents, although this is the most important item the programme should include. In Čáslav and Pelhřimov, there is at least an overview of the previous years, but in the remaining two municipalities it is not so. These programmes (except for the document of Pelhřimov) suffer from the problem that they are drawn up each year and are not guided by any long-term objectives or priorities. The towns declare their regeneration programmes publicly, always at the end of the calendar year. All those owning a cultural property in the protected conservation area then can join it. Out of the arisen list of bidders, only a few bidding projects are eventually selected according to the size of the received subsidy. This means that the development is not guided by any concept, but rather in a random fashion. This evokes the feeling that regeneration programmes are really only an instrument which can help to acquire finances from the subsidy titles of the Czech Ministry of Culture.

\section{Discussion}

Although strategic planning is considered one of the basic blueprints for the development of municipalities, there was a surprising finding that out of the 24 selected towns only 21 had the strategic plan. Given the size of the municipalities and financial costs of the drafting of these documents, the assumption that the community method of drafting may be chosen was not confirmed. On the contrary, only 5 towns applied this method. Tourism was taken into account in two-thirds of the towns in the formulation of a development vision that is generally considered a positive outlining of the future image of the municipality. Tourism fared even better in comparison with other development axes. It was not mentioned only in two cases, being only outstripped by the development axis dealing with business and employment. According to the available texts, some towns (Kutná Hora, Vysoké Mýto) want to keep encouraging tourism. Others see themselves 
as major destinations (Beroun, Jaroměř, Kadaň, Klatovy, Rakovník) and the rest focus on the development of tourism-related services (Mělník, Nymburk, Ostrov, Slaný, Žatec). When it comes to the support for tourism, the highest level of the drafting of strategies was found in the town of Beroun, Kadaň, Nymburk, Ostrov, Rakovník, Slaný, Tachov, and Žatec, primarily thanks to the detailed project reserve. A slightly worse evaluation was given to the strategies of the town of Domažlice, Dvưr Králové nad Labem, Klatovy, Pelhřimov, and Prachatice, primarily due to their ignorance of detailed working techniques. No specific tasks have so far been outlined by the town of Jaroměř, Mělník, Kutná Hora, Chrudim, Litoměřice, and Sušice as well as the town of Písek and Vysoké Mýto. For them, the support for tourism is not the most important aspect of development.

In these towns, the potential for tourism development is primarily offered by the cultural heritage. The towns are aware of this, paying varying attention to their protected conservation areas and cultural heritage. In all the evaluated towns, this is evidenced by the drafted regeneration programmes, although the structure and quality of elaboration of individual documents strongly differ. The quality of elaboration depends neither on the type nor the size of the protected area or town. When it comes to the quality of elaboration of the regeneration programmes, unmistakable differences were uncovered. They often evoke the feeling that the towns have only drawn up the documentation in order to be eligible for the state financial support (Čáslav, Jaroměř, Pelhřimov, Žatec). However, there are also the municipalities in which the heritage conservation is conducted in a systematic way and the repair of the cultural heritage would happen at any rate (Chrudim, Litoměřice, Prachatice, Slaný, Sušice, Vysoké Mýto).

It was observed whether the towns use the historical domain of "royal city" as a quality trademark for their promotion. This situation was already explored at the level of development visions of the towns. The authors found out that only 4 examined royal towns (Litoměřice, Mělník, Nymburk, Pelhřimov) mention this historical title. Due to this alarming result, research into the entries in the headings of official web pages of the examined towns was also carried out. However, there were no favourable results because only the town of Beroun, Kadaň, Rakovník, Slaný, and Žatec proudly display this domain.

Based on the analysed documents and secondary data, one can cite two extreme examples with regard to the tourism development strategy. The town of Prachatice is a typical example of an increased interest in support for tourism, along with a high value of tourist function. Quite the opposite behaviour can be most apparently observed in the town of Písek. A specific attitude is assumed by Kutná Hora. This is given by its status of a UNESCO-listed town, where the tourism development and heritage protection are dealt with by other documents than those analysed here.

\section{Conclusion}

The medium-sized historical towns in Czechia have at their disposal a preserved cultural heritage which constitutes important potential for tourism. Based on the intensification indicators calculated from the publicly accessible data, this study answers the 
question of what the position of tourism in the selected towns (Czech royal towns with the population size between 10,000 and 30,000 inhabitants) is. Based on strategic documents it analyses what were the strategies chosen by the selected royal towns for their development and whether the topic of tourism that can undoubtedly rely on its historical potential, declared by legislative protection of cultural heritage, is represented and what is its importance. The findings of this study reveal that the support for the tourism development primarily depends on the amount of financial means and other, specific problems of each town. However, a long-term tourism development in the destination, too, to some extent determines the motivation of future behaviour and a conceptual development. Some of the analysed royal towns provide detailed, elaborate development proposals and one cannot doubt about their effort to improve the current situation. On the other hand, there are still the municipalities that are not fully aware of the benefits brought by tourists to a given area and have not proceeded to outline a conceptual support for tourism. One can only hope that the level and subsequent applicability of the strategic documents and regeneration programmes will be rising in the future and that the support for tourism, along with the effort to save the cultural wealth, will enjoy growing popularity.

\section{Acknowledgement}

The article was written within the framework of The Historical Geography Research Centre, Excellence grant project of the Czech Science Foundation P410/12/G113.

\section{References}

Albrechts, L., \& Balducci, A. (2013). Practicing strategic planning: in search of critical features to explain the strategic character of plans. The Planning Review, 49(3), 16-27. DOI: $10.1080 / 02513625.2013 .859001$.

Albrechts, L., Haley, P., \& Kunzmann, K. R. (2003). Strategic spatial planning and regional governance in Europe. Journal of the American Planning Association, 69(2), 113-129.

Bohemian Royal Towns. (2013). ABCD - VIDEO, spol. s r.o., (documentary film), [cit. 23. 1. 2016].

CZSO. (2016a). Počet obyvatel v obcich České republiky k 1. 1. 2016 (Population in the municipalities of the Czech Republic). [online]. Prague: Czech Statistical Office. Retrieved from March 3, 2016 https://www.czso.cz/documents/10180/32853387/1300721603.xlsx/808f4866-35e6-4d4f-95ec-962c5e5f1588?version=1.0.

CZSO. (2016b). Obce České republiky 2016 (Municipalities of the Czech Republic). [online]. Prague: Czech Statistical Office. Retrieved April 6, 2017 from https://www.czso.cz/documents/10180/50418271/32019916102.pdf/ae43eec8-0fd6-46ba-acad-6d6cebf40320?version=1.1

Dumbrovská, V., \& Fialová, D. (2014). Tourist Intensity in Capital Cities in Central Europe: Comparative Analysis of Tourism in Prague, Vienna and Budapest. Czech Journal of Tourism, 3(1), 5-26. 
Dumbrovská, T., \& Fialová, D. (2016). Turistické okrsky a turistifikace v Praze: případová studie Královské cesty (Tourist precincts and touristification in Prague: The Royal Route case study). Studia Turistica, 7(1), 6-17.

Fialová, D., \& Nekolný, L. (2015). Rub a líc turistické přitažlivosti (Two Sides of Tourist Attractiveness.). Geografické rozhledy, 24(4), 8-9.

Fialová, D., \& Nekolný, L. (2017). Řečí čísel cestovního ruchu (Tourism by the Numbers). Geografické rozhledy, 26(3), 22-23.

Healey, P. (2000). The treatment of space and place in the new strategic spatial planning in Europe. In G. Bridge \& H. Watson (Eds.), A Companion to the City (pp 517-530). Oxford: Blackwell. In L. Albrechts \& A. Balducci (2013), Practicing strategic planning: in search of critical features to explain the strategic character of plans (p. 18). The Planning Review, 49(3), 16-27. DOI: 10.1080/02513625.2013.859001.

Hirschman, A. O. (1970). Exit, Voice, and Loyalty: Responses to Decline in Firms, Organizations, and States. Cambridge, USA/London, UK: Harvard University Press.

Ježek, J. (2013). Strategické plánování obcí a měst: Nové přístupy a cesty k jeho zefektivnění (Strategic urban planning: New approaches and the ways how to streamline it). In V. Žítek \& V. Klímová (Eds.), XVI. International Colloquium on Regional Sciences (pp. 372-376). Brno: Masaryk University.

Jiroutová, N. (2017). Hodnoceni strategických dokumentů českých královských měst střední velikosti z

hlediska cestovniho ruchu (Evaluation of Strategic Planning in Terms of Tourism in Czech Royal Middle-Sized Cities). Diploma thesis. Prague: Charles University.

Kašková, M., \& Chromý, P. (2015). Přitažlivost "značkových" míst (The Attractiveness of "Branded" Places). Geografické rozhledy, 24(4), 10-11.

Legner, O. (2017). Výstup z veřejné databáze ČSÚ (Output from the public database CZSO). Retrieved March 16, 2017 from https://vdb.czso.cz/vdbvo2/faces/cs/index.jsf?page=vystup-objekt\&pvo=UD-1489574919264\&z=T\&f=TABULKA\&udIdent=-102044\&str=v10002\&.

Machová, P. (2016). Vliv turismu na památky UNESCO Český Krumlov a Telč (The influence of tourism on the UNESCO sights Cesky Krumlov and Telc). Diploma thesis. Prague: Charles University.

Matlovičová, K. (2015). Značka územia (Place brand). Prešov, SK: Prešov University.

McCourt, W. (2013). Models of Public Service Reform: A Problem-Solving Approach. The World Bank, No. 6428.

McCourt, W., \& Minogue, M. (2001). The Internationalization of Public Management: Reinventing the Third World State. Cheltenham, UK: Edward Elgar Publishing.

Ministry of Culture. (2016). Dotačni programy Ministerstva kultury a jejich vyhodnoceni (Subsidy Programmes of the Ministry of Culture and Their Evaluation). [online]. Retrieved May 16, 2016 from http://www.mkcr.cz/dotacni-programy-ministerstva-kultury-a-jejich-vyhodnoceni-267.html.

Ministry of Culture. (2012). Opatřeni MK $\check{C} R$ (Measures of the Ministry of Culture of the Czech Republic) č. j. 63.382/2012 OPP.

National Heritage Institute. (2016). Central List of Cultural Monuments of the Czech Republic. [online]. Retrieved September 21, 2016 from http://monumnet.npu.cz/chruzemi/hledani.php.

Pásková, M., \& Zelenka, J. (2002). Výkladový slovnik cestovniho ruchu (Tourism - explanatory dictionary). Prague: Ministry for Regional Development.

Perlín, R. (2001). Strategický plán mikroregionu: Metodická přiručka pro zájemce o strategické plánování ve venkovských mikroregionech a obcich (Microregional strategic plan: A methodic guide for strategic prospects planning in rural micro-regions and municipalities). Prague: Charles University. 
Řehoř, P. (2010). Strategický plán rozvoje obcí (Strategic development plan for municipalities). Auspicia, 7(1), 34-37.

Tittelbachová, Š. (2008). Politika cestovního ruchu (Tourism Policy). In R. Wokoun, J. Malinovský, M. Damborský, \& J. Blažek (Eds.), Regionálni rozvoj: východiska regionálního rozvoje, regionální politika, teorie, strategie a programováni (Regional development: (bases regional development, regional policy, theory, strategy and programming) (pp. 205-215). Prague: Linde.

UNESCO. (2016). The Czech heritage UNESCO. [online]. Retrieved November 1, 2016 from http:// www.unesco-czech.cz/.

Vystoupil, J., Holešinská, A., Kunc, J., Maryáš, J., Seidenglanz, D., Šauer, M., \& Viturka, M. (2006). Atlas cestovniho ruchu České republiky (Atlas of Tourism of the Czech Republic). Prague: Ministry for Regional Development.

Vystoupil, J., Šauer, M., Holešinská, A., Kunc, J., Tonev, P., \& Seidenglanz, D. (2011). Geografie cestowniho ruchu České republiky (Geography of Tourism in the Czech Republic). Plzeň: Aleš Čeněk.

Word cloud [online]. Better Evaluation. Retrieved September 15, 2016 from http://betterevaluation.org/evaluation-options/wordcloud.

\section{Sources for Table 2}

[1] Seznam městských památkových zón v Česku (List of urban monument areas in the Czechia). [online]. Wikipedia. Retrieved January 23, 2017 from https://cs.wikipedia.org/wiki/Seznam_m\%C4\%9Bstsk\%C3\%BDch_pam\%C3\%A1tkov\%C3\%BDch_z\%C3\%B3n_v_\%C4\%8Cesku.

[2] Seznam městských památkových rezervaci v Česku (List of urban monument reservations in the Czechia) [online]. Wikipedia. Retrieved January 23, 2017 from https://cs.wikipedia.org/wiki/ Seznam_m\%C4\%9Bstsk\%C3\%BDch_pam\%C3\%A1tkov\%C3\%BDch_rezervac\%C3\%AD_v_\%C4\%8Cesku.

[3] Ministry of Culture. (1992). Vyhláška MK ČR č. 476/1992 Sb. o prohlášeni území historických jader vybraných měst za památkové zóny (Decree of the Ministry of Culture No. 476/1992 Coll. to declare the territory of the historical centre of selected cities as monumental areas).

[4] Ministry of Culture of Czechoslovakia. (1975). Výnos MK ČSR čj. 17.596/75-VI/1 ze dne 31. 10. 1975 o prohlášeni historického jádra města Domažlic za památkovou rezervaci (Yield of the Ministry of Culture of Czechoslovakia ref. 17.596 / 75-VI / 1 of 31 October 1975 on the declaration of the historical centre of Domažlice for a monument reservation).

[5] Ministry of Culture of Czechoslovakia. (1981). Výnos MK ČSR čj. 16.428/81-VI/1 ze dne 6. 10. 1981 o prohlášeni historického jádra města Prachatic za památkovou rezervaci (Yield of the Ministry of Culture of Czechoslovakia ref. 16.428 / 81-VI / 1 of 6 October 1981 on the declaration of the historic core of Prachatic for a monument reservation).

[6] East Bohemia Region. (1990). Vyhláška Východočeského KNV ze dne 17. 1.1990 o prohlášení památkových zón ve vybraných městech a obcích Východočeského kraje (Decree of the East Bohemian RNC of 17 January 1990 on the declaration of monument areas in selected cities and the municipalities of the East Bohemia Region. 
[7] Ministry of Culture of Czechoslovakia. (1971). Výnos MK ČSR čj. 4.903//71-II/2 o prohlášeni historického jádra města Josefova (dnešni Jaroměr II) za památkovou rezervaci (Decree of the Ministry of Culture of the Czechoslovak Republic ref. 4.903 // 71-II / 2 about the declaration of the historical nucleus of the city of Josef for a monument reservation).

[8] Ministry of Culture of Czechoslovakia. (1969). Výnos MK ČSR čj. 11.764/69-II/2 ze dne 10. 9. 1969 o prohlášeni historického jádra města Pelhřimova za památkovou rezervaci (Yield of the Ministry of Culture of Czechoslovakia ref. 11.764 / 69-II / 2 dated 10. 9. 1969 on the declaration of the historical center of Pelhřimov for a monument reservation).

[9] Ministry of Culture of Czechoslovakia. (1978). Výnos MK ČSR čj. 15.868/78-VI/1 ze dne 10. 5. 1978 o prohlášeni historického jádra města Kadaně za památkovou rezervaci (Yield of the Ministry of Culture of Czechoslovakia ref. 15.868 / 78-VI / 1 of 10.5.1978 concerning the declaration of the historical nucleus of the city of Kadaň for a monument reservation).

[10] Ministry of Education and Culture. (1961). Výnos MŠK čj. 36.568/61-V/2 o prohlášeni městské památkové rezervace v Kutné Hoře, Táboře, Jindřichově Hradci, Slavonicich, Žatci a zř́zeni archeologické památkové rezervace Slavnikouská Libice (Yield of MŠK Ref. 36.568 / 61-V / 2 on the declaration of the urban monument reserve in Kutná Hora, Tábor, Jindřichův Hradec, Slavonice, Žatec and the establishment of Slavníkovská Libice archaeological heritage site).

[11] Ministry of Culture of Czechoslovakia. (1975). Výnos MK ČSR čj. 22.260/78-VI/1 ze dne 27. 10. 1978 o prohlášeni historického jádra města Litoměric za památkovou rezervaci (Yield of the Ministry of Culture of Czechoslovakia ref. 22.260 / 78-VI / 1 of 27 October 1978 on the declaration of the historical center of Litoměřice for a monument reservation).

[12] South Bohemian Region. (1990). Vyhláška Jihočeského KNV ze dne 19. 11.1990 o prohlášení památkových zón ve vybraných městech a obcich Jihočeského kraje (Decree of the South Bohemian RNC of 19 November 1990 on the declaration of monument areas in selected cities and municipalities of the South Bohemian Region.

[13] Sdružení historických sídel Čech, Moravy a Slezska (The Association of Historical Settlements in Bohemia, Moravia and Silesia). (2017). Karta města Domažlice (Map of Domažlice). [online]. Retrieved May 17, 206 from http://historie.shscms.cz/emapa/Plzensky-kraj/Domazlice/.

[14] Městský program regenerace MPZ Sušice (Municipal regeneration program of UMZ Sušice). (2015). AF - CityPlan, s.r.o. Praha. [online]. Retrieved January 20, 2016 from http:/ /www.mestosusice.cz/ mususice/user/deska/OSPPCR/pamatakova_pece/Program\%20regenerace\%20MPZ_Susice.pdf.

[15] Strategický plán rozvoje města Prachatice (Strategic plan for the development of the town of Prachatice). (2016). Městský úřad Prachatice (City Authority Prachatice). [online]. Retrieved July 18, 2016 from http://www.prachatice.eu/sites/default/files/docs/podnikani/strategicky_plan.pdf.

[16] Program regenerace Městské památkové zóny Vysoké Mýto 2014-2023 (Regeneration program of the Urban monument zones Vysoké Mýto 2014-2023). (2015). [online]. Retrieved July 29, 2016 from http:// projekty.vysoke-myto.cz/images/stories/strategicke_dokumenty/Program_regenerace_MPZ_Vysoke_Mto_2014-2023_aktualizace_listopad-2015.pdf.

[17] Program regenerace Městské památkové zóny Jaroměr a Městské památkové rezervace (Josefov Regeneration program of the Jaroměr Urban monument area and Urban monument reserve Josefov). [online]. Informační portál města Jaroměře. Retrieved November 21, 2016 from http://www.jaromer-josefov.cz/mestsky-urad/odbory-mu-1/odbor-vystavby/pamatkova-pece/. 
[18] Městská památková zóna Nymburk (Urban monument zone Nymburk). [online]. Město Nymburk. Retrieved September 9, 2016 from http://www.mesto-nymburk.cz/infocentrum/index. php?stranka=mpz-d.

[19] Program regenerace MPZ ve Slaném pro roky 2014-2018 (Regeneration program UMA Slaný for 2014-2018). (2013). [online communication].

[20] Památky Pelhřimovsko (Monuments Pelřimovsko). [online]. Informační server města Pelhřimova. Retrieved August 5, 2016 from http://www.pelhrimovsko.cz/cz/turisticky-servis/pamatky. html.

[21] Vystyd, L. (2010). Program regenerace Městské památkové zóny Ostrov 2010-2020 (Regeneration program Urban monument area Ostrov 2010-2020)., 46 s. [online]. Retrieved September 10, 2016 from http://www.ostrov.cz/rozvoj-program-regenerace-mestske-pamatkove-zony/d-2244/p1=2.

[22] Červená, J. [online communication from September 21, 2016]. Městský úřad Kadaň. (City Authority Kadaň).

[23] UPA Beroun. (2016). Program regenerace MPZ Beroun na obdobi 2016-2019 (Regeneration program UPA Beroun for the period 2016-2019). Městský úřad Beroun (City Authority Beroun).

[24] Šilhavá, P. [online communication from September 21, 2016]. Městský úřad Žatec (City Authority Žatec), silhava@mesto-zatec.cz.

[25] Kutná Hora - Management plán (Managment Plan). (2011). [online]. Město Kutná Hora (City Authority Kutná Hora). Retrieved September 9, 2016 from http://mu.kutnahora.cz/file/981/ download/.

[26] Přihláška do soutěže o Cenu za nejlepši př́pravu a realizaci Programu regenerace MPR a MPZ za rok 2015 (Application for the Prize for Best Preparation and Implementation of the UMR and UMZ Regeneration Program for 2015). (2016). [online]. Město Klatovy. Retrieved March 2, 2016 from www.historickasidla.cz/filemanager/files/file.php?file=203081.

[27] Pilařová, E. [online communication from September 21, 2017]. Městský úřad Chrudim (City Authority Chrudim).

[28] Patůček, M. (2014). Program regenerace MPR Litoměřice (Regeneration program of UMR Litoměřice). [online]. Retrieved September 12, 2016 from https://www.litomerice.cz/images/Clanky/ sksapp/program_regenerace_mpr_litomice_2015-2020.pdf.

[29] Hodnocení a aktualizace Programu regenerace Městské památkové zóny Čáslav 2015 (Evaluation and update of the regeneration program of the Čáslav 2015 Urban Monument Zone). (2016). [online communication from July 28, 2016]. Městský úřad Čáslav (City Authority Čáslav).

[30] Seznam nemovitých kulturních památek v MPR Domažlice (List of immovable cultural monuments in UMR Domažlice). [online]. Oficiální stránky města Domažlice. Retrieved March 9, 2016 from http://www.domazlice.eu/mestsky-urad/pamatkova-pece/mestska-pam-rezervace/?mo$\mathrm{re}=771 \# \operatorname{msg} 771$.

[31] UMA Vysoké Mýto. [online]. Národní památkový ústav - MonumNet. Retrieved July 29, 2016 from http://monumnet.npu.cz/chruzemi/list.php?IdCis=ZM\%2C144.

[32] Tachov - městská památková zóna. (2005). [online]. Město Tachov. Retrieved March 15, 2016 from http://www.tachov-mesto.cz/pamatky/mpz-tachov.pdf. 
[33] Památky a občanská vybavenost Plzeňského kraje - Rokycany (Monuments and amenities of the Pilsen Region - Rokycany). [online]. Plzeňský kraj. Retrieved March 17, 2016 from http://www. plzensky-kraj.cz/cs/relics.asp?lngZone=10729.

[34] UMA Dvůr Králové nad Labem. [online]. Národní památkový ústav (National Heritage Institute) - MonumNet. Retrieved September 21, 2016 from http://monumnet.npu.cz/chruzemi/list. php?IdCis=ZM\%2C133.

[35] UMA Rakovník. [online]. Národní památkový ústav (National Heritage Institute) - MonumNet. Retrieved September 21, 2016 from http://monumnet.npu.cz/chruzemi/list.php?IdCis=ZM\%2C33.

[36] UMR Kadaň. [online]. Národní památkový ústav (National Heritage Institute) - MonumNet. Retrieved September 20, 2016 from http://monumnet.npu.cz/chruzemi/list.php?IdCis=RM\%2C18.

[37] Program regenerace Městské památkové zóny na obdobi let 2011-2015 - Aktualizace srpen 2014 (Regeneration program of the Urban monument area for 2011-2015 - Update August 2014). (2014). Městský úřad Louny (City Authority Louny).

[38] UMA Mělník. [online]. Národní památkový ústav (National Heritage Institute) - MonumNet. Retrieved September 21, 2016 from http://monumnet.npu.cz/chruzemi/list.php?IdCis=ZM\%2C19.

[39] Václavík, F. (2012). Program regenerace Městské památkové zóny Chrudim na roky 2013-2023 (Regeneration program of the Urban monument area). [online communication from September 20, 2016]. Městský úřad Chrudim.

[40] UMA Písek. [online]. Národní památkový ústav (National Heritage Institute) - MonumNet. Retrieved September 21, 2016 from http://monumnet.npu.cz/chruzemi/list.php?IdCis=ZM\%2C48.

\section{Other Strategic Plans and Regeneration Programmes of the Selected Towns:}

Městský program regenerace Městské památkové rezervace Kadaň (Municipal regeneration program of Urban monument zone Kadaň. (2013). [online]. Město Kadaň. Retrieved September 11, 2016 from http://www.mesto-kadan.cz/dokumenty/mrp/Prog_regeneraceMPRKadan.pdf.

Program regenerace Městské památkové rezervace Prachatice (Regeneration program Urban monument reserve Prachatice). (2016). [online]. Město Prachatice. Retrieved January 28, 2016 from http://www.prachatice.eu/sites/default/files/docs/program_mpr_2016_2018.pdf.

Strategický plán Kadaně (Strategic plan of Kadaň). (2004). [online]. Retrieved September 11, 2016 from http:/ / www.mesto-kadan.cz/dokumenty/spk2004.pdf.

Strategický plán města Mělníka (Strategic plan of the city Mělník). (2012). [online]. RegioPartner, s.r.o. \& AQU Advisors, a.s. Retrieved September 12, 2016 from http://www.melnik.cz/VismoOnline_ActionScripts/File.ashx?id_org=9281\&id_dokumenty=3149.

Strategický plán rozvoje města Beroun (Strategic development plan of the city Beroun). (2005). [online]. DHV CR, spol. s r. o. Retrieved September 11, 2016 from http://www.mesto-beroun.cz/ podnikatel/rozvoj-mesta/strategicky-plan/. 
Strategický plán rozvoje města Kutná Hora, Akční plán ve znění 1. až 3. aktualizace (Strategic development plan of the city Kutná Hora, action plan as amended by 1st and 3rd updates). (2004). [online]. BermanGroup. Retrieved September 12, 2016 from http://mu.kutnahora.cz/mu/strategicka-plan-rozvoje-mesta.

Strategický plán rozvoje města Litoměřice (Strategic development plan of Litoměřice. (2012). [online]. Retrieved September 12, 2016 from https://www.litomerice.cz/images/Clanky/opas/ SPRM_2012_FINAL_pro_web-2014.pdf.

Strategický plán rozvoje města Ostrova (Strategic development plan of the city Ostrov), (2005). [online]. Městský úřad Ostrov. Retrieved September 10, 2016 from http://www.ostrov.cz/rozvojstrategicky-plan-rozvoje-mesta-ostrov/ds-1162/p1=2532.

Strategický plán rozvoje města Pelhřimov na období 2014-2020 (Strategic development plan of the city Pelhřimov). (2013). [online]. Město Pelhřimov. Retrieved August 2, 2016 from http://www. mupe.cz/VismoOnline_ActionScripts/File.ashx?id_org=11891\&id_dokumenty=10375.

Strategický plán rozvoje města Rakovník do roku 2022 (Strategic plan for the development of the city of Rakovník until the year 2022). (2013). DHV CR, spol. s r.o. [online]. Retrieved September 10, 2016 from http:/ / www.mesto-rakovnik.cz/e_download.php?file=data/editor/405cs_1.pdf\&original=Strategick\%C3\%BD+pl\%C3\%A1n+do+r.+2022+Rakovn\%C3\%ADk+13.+11.+2013.pdf.

Strategický plán rozvoje města Slaný (Strategic Development Plan of Slaný). (2013). HaskoningDVH Czech Republic, spol. s r.o. [online]. Retrieved September 9, 2016 from http://www.meuslany.cz/cs/dokumenty-mesta/strategicky-plan-rozvoje-mesta-slany-2013/.

Strategický plán rozvoje města Žatce (Strategic development plan of the city Žatec). (2015). [online]. Regionální rozvojová agentura Ústeckého kraje, a.s. Retrieved September 12, 2016 from http:/ / www.mesto-zatec.cz/e_download.php?file=data/editor/51cs_2.pdf\&original=Strategicky+plan+\%C5\%BDatec_2015_2020_verze+20_8_2015.pdf.

Strategický plán udržitelného rozvoje města Chrudimi 2015-2030 (Strategic sustainable development plan of the city of Chrudim 2015-2030). (2014). [online]. Regionální rozvojová agentura Pardubického kraje. Retrieved September 12, 2016 from http://www.chrudim.eu/mesto/strategicke-dokumenty/strategicky-plan-udrzitelneho-rozvoje-mesta-chrudimi-2015-2030-.html.

Strategie rozvoje města Dvůr Králové nad Labem (Strategic development plan of the city Dvůr Králové nad Labem). (2016). [online]. DRAG s.r.o. Trutnov. Retrieved August 10, 2016 from http:// www.mudk.cz/cs/rozvoj/rozvoj-mesta/strategie-rozvoje-2016-2022/zastupitele-schvalili-programrozvoje-mesta-na-obdobi-2016-2022.html.

Strategie rozvoje města Klatovy v letech 2010-2015 (Strategic development plan of the city Klatovy). (2010). [online]. Rada města Klatov. Retrieved February 22, 2016 from http:/ /www.klatovy.cz/ mukt/user/ruzne/strategie_rozvoje_klatovy.pdf.

Strategie rozvoje města Nymburk na léta 2011-2020 (Nymburk development strategy for 20112020). (2010). [online]. Nexia AP, a.s. Retrieved September 9, 2016 from http://www.mesto-nymburk.cz/index.php?sekce=1\&zobraz=strategie-rozvoje-mesta.

Strategie rozvoje města Sušice (Development strategy of the town of Sušice). (2005). Plzeň: Západočeská univerzita. 